\title{
بين مفهومي الجهاد والإرهاب: دراسة في المفهوم والأهداف لحركة القاعدة وتنظيم داعش أنموذجا
}

\section{Between Jihäd and Terrorism: An Introspection on Its Concepts and Purposes with Reference to the al-Qaeda and ISIS Movements}

\author{
Muhamad Sayuti Mansor* \\ Mohamad Azwan Kamarudin**
}

\begin{abstract}
In the aftermath of the September 11 attacks, Islam has fell victim to the allegation that relates it to terrorism. This is due to the rise of terrorist movements such as al-Qaeda and ISIS that claim to be representing Islam and pursuing the holy war (jihād) to establish an Islamic caliphate (al-khiläfah al-Islamiyyah). These terrorist movements also used the same terms and concepts that can be found in the traditional Muslim scholarship, such as the abode of Islam and the abode of war (dār al-Istām wa dār alharb), loyalty and disavowal (al-walà' wa al-barā'), and excommunicating Muslims (takfir). Thus, this study seeks to analyse these two concepts of jihadd and terrorism (irhāb) to locate both their similarities
\end{abstract}

* Analyst, International Institute of Advanced Islamic Studies (IAIS) Malaysia, Kuala Lumpur. sayuti@iais.org.my

** Arabic Language Teacher, Faculty of Islamic Studies, Universiti Kebangsaan Malaysia, Selangor. azwankamarudin@ukm.edu.my 
and differences. Comparison is made from several aspects such as etymology and history and lastly its application in our contemporary reality in relation to other relevant terms and concepts as mentioned above. This study finds that there are substantial differences between jiha $\bar{a} d$ and irha $\bar{b}$, and it is the failure to grasp the ever evolving and developing nature of Islamic law (figh) and the contemporary reality that led to this confusion.

Keywords: Islam, terrorism, jihad, Islamic state, caliphate

إن الإسلام دين شامل ونظام متكامل يغطي كافة جوانب إصلاحات

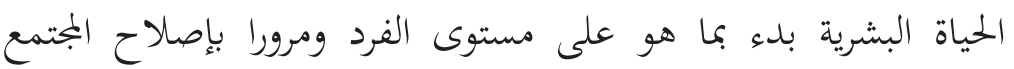

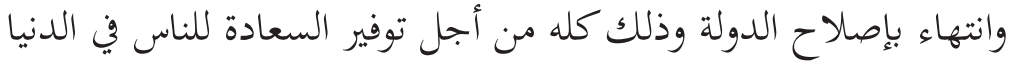

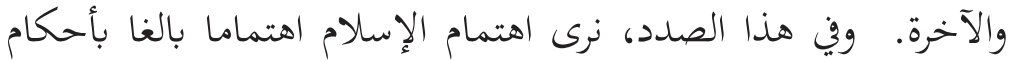

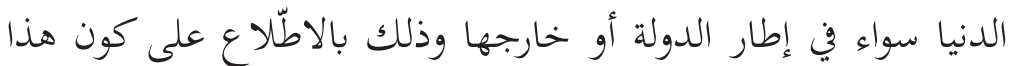

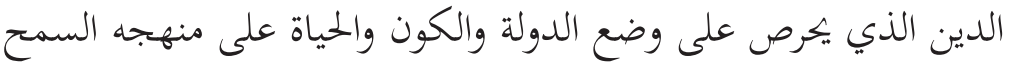
ولا يفصل يومًا بين الدين والدولة بخلاف ما هوضي هو شأنه في الديانة المسيحية.

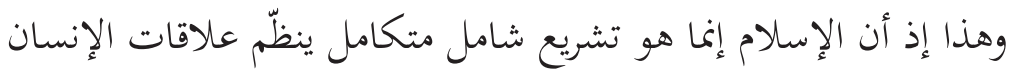

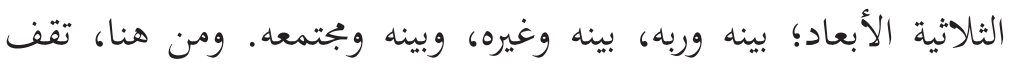

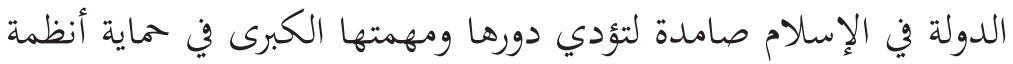

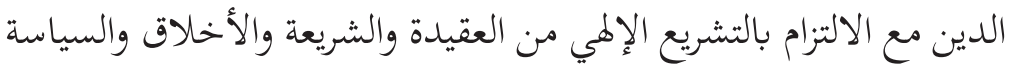

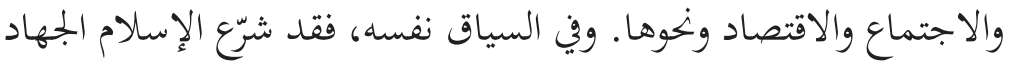

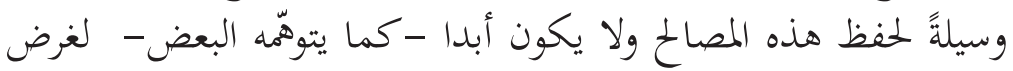

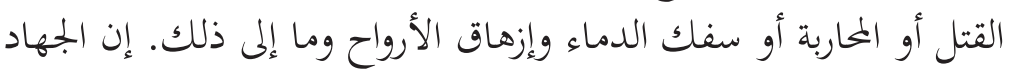

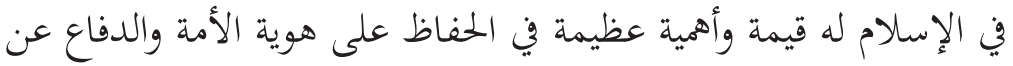

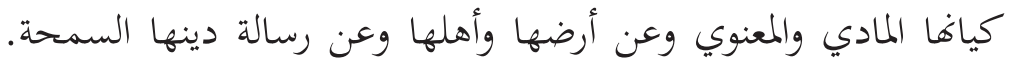


فبدون الجهاد، أصبحت الرسالة الإسلامية مسدودة الطرق محصورة

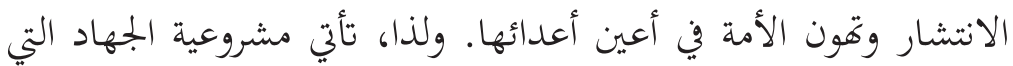
هي من أهم خصائص هذا الدين.

وأما قضية الإرهاب واستعمال وسائل العنف في حل المشكلة فهي

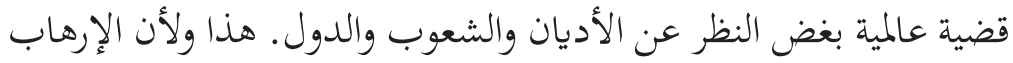

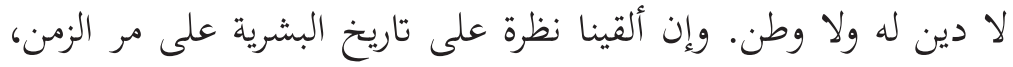

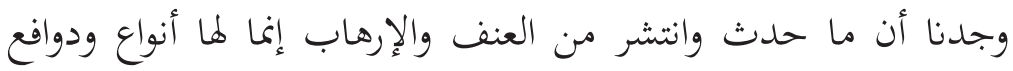

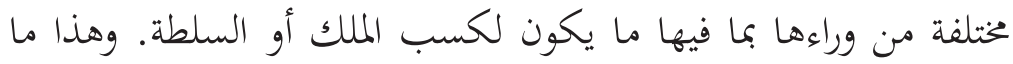

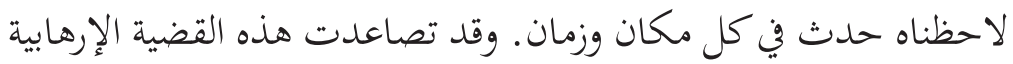

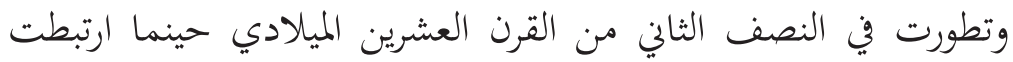
قضية الإرهاب بعامل الدين ولا سيما بدين الإسلام.

وهذا يظهر بوضوح عقب سلسلة من الحروب خاضها الشعوب في

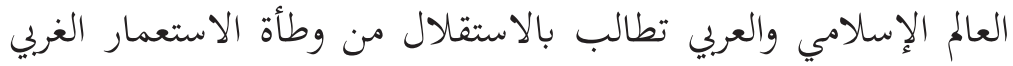

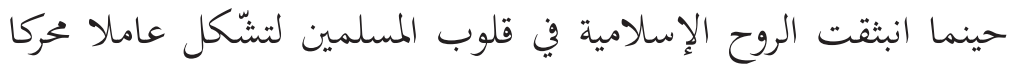

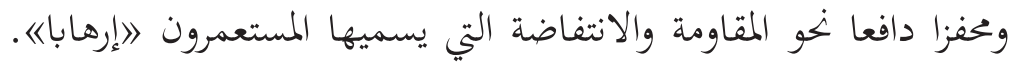

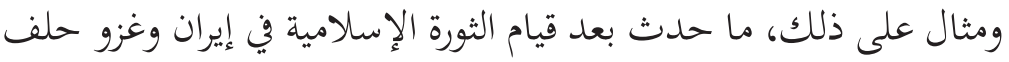

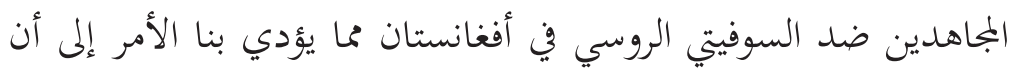

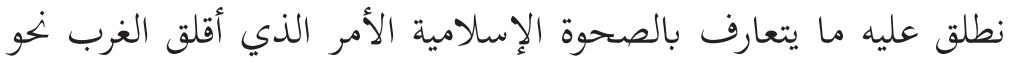

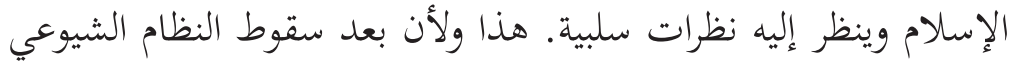

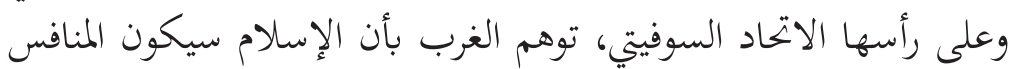

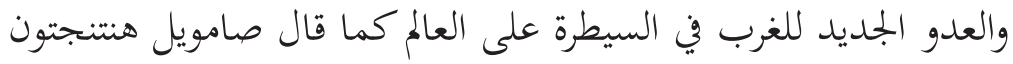

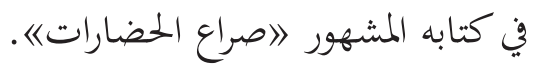

ولقد أصبحت هذه القضية أكثر خطورة بعد حادثة الهجوم الجوي

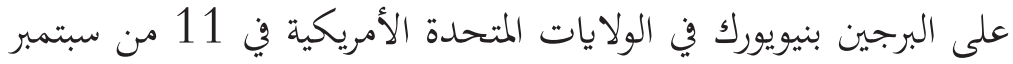


حيث أعلنت أمريكا بالحرب العالمية على الإرهاب تستهدف الحركات

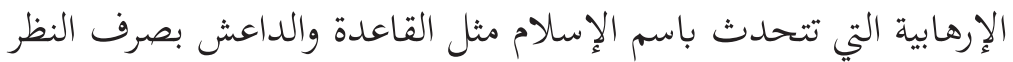

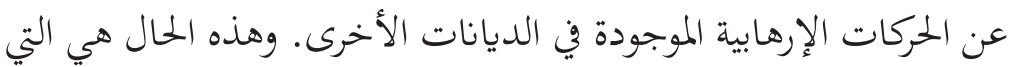

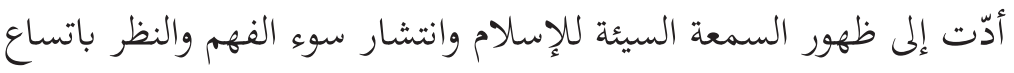

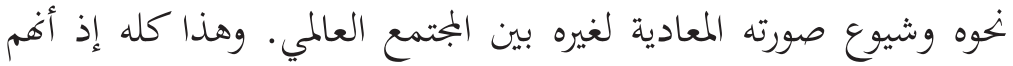

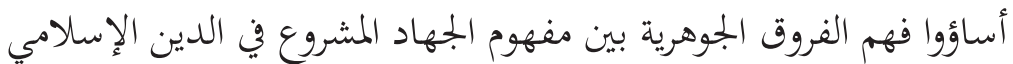

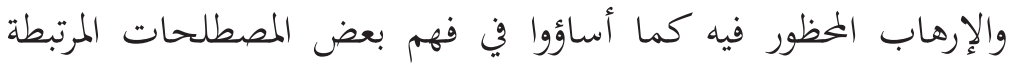

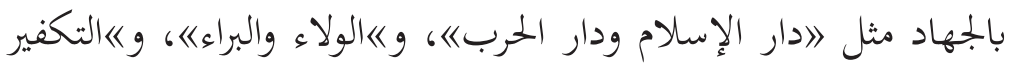

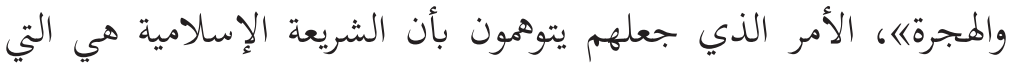
تنشئ تلك الفكرة الإرهابية.

وعلى ذلك، يرمي هذا البحث إلى بيان الفروق الجوهرية بين مفهوم

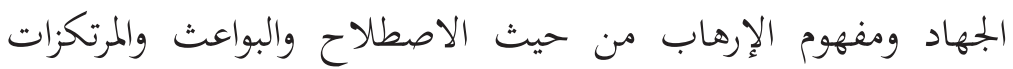

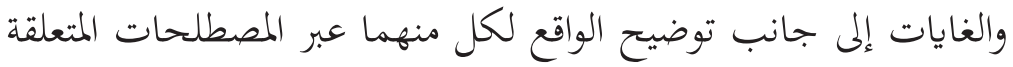

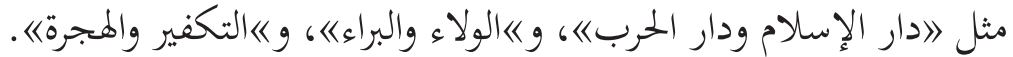

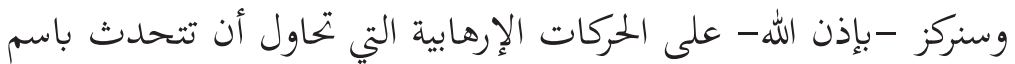

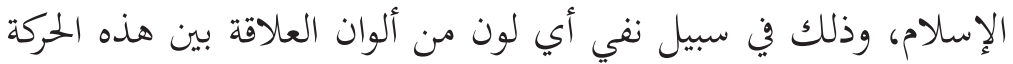

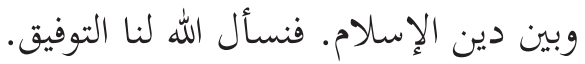

\section{مفهوم الجهاد في الإسلام}

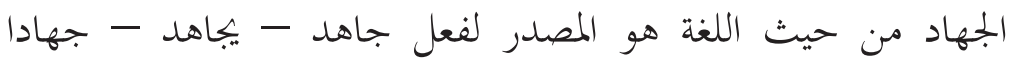

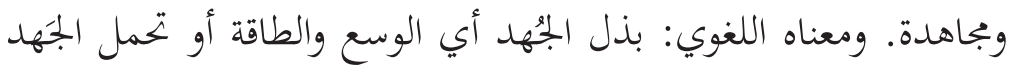

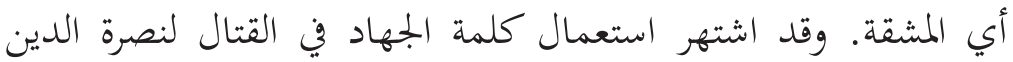

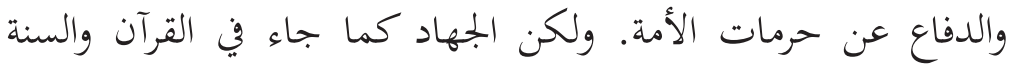

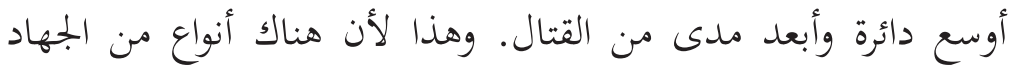

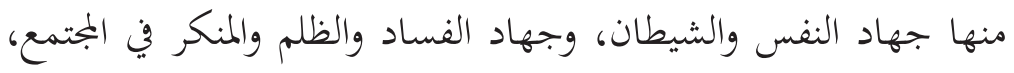


وجهاد المنافقين وجهاد الدعوة والبيان، وجهاد الصبر والاحتمال وما سميناه

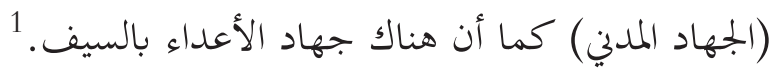

وأما القتال فهو فقط للشعبة الأخيرة من شُعب الجهاد وهو القتال

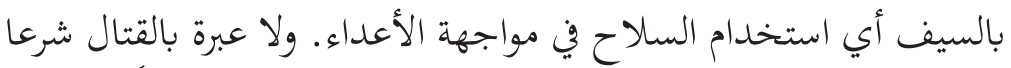

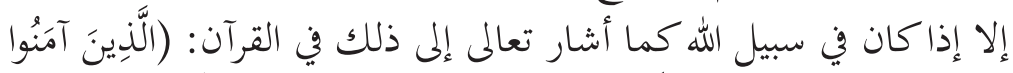

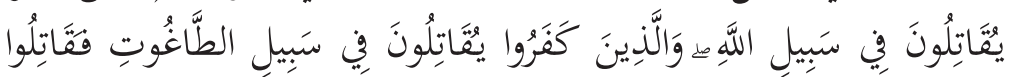

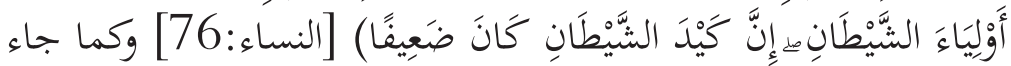

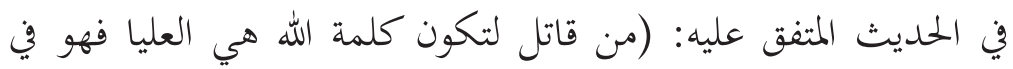

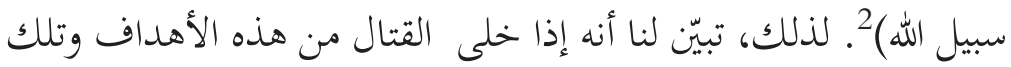

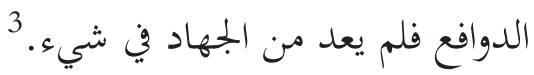

والحق أن مفهوم الجهاد في الاسلام ليس مرادفا دائما للقتال، فالجهاد مفهوم واسع فهو دفاع عن الحق ودعوة إليه باللسان كما ذكر في القرآ آنان:

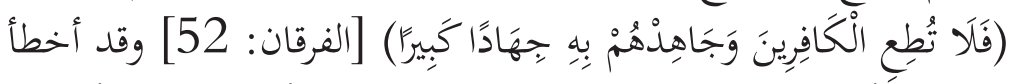

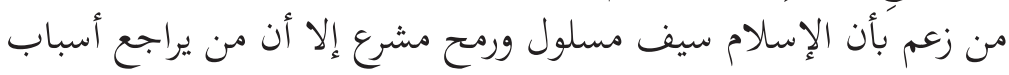

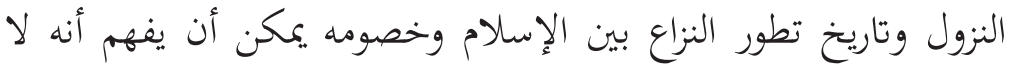

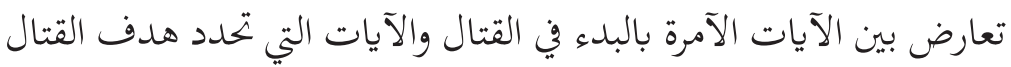

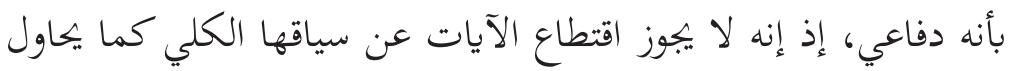

Yūsuf al-Qaraḍāwī, Fiqh al-Jihād: Dirāsah Muqāranah li Ahkāmihi wa Falsafatihi fì Daw'al-Qur'ān wa al-Sunnah (Qāhirah: Maktabah Wahbah, 2009), 55.

2 'Abd Allah Muḥammad Ismā'īl, al-Bukhārī, al-Jāmi' al-Sahīh alMusnad min Hadìth Rasūl Allah wa Sunanuhu wa Ayyāmuhu, Kitāb al-Jihād wa al-Siyar, Bāb Man Qātala li Takūnu Kalimat Allah hiya al-'Ulyā (Qāhirah: Būlāq, 1422H), no. hadith 2810; Muslim ibn Hajjāj al-Naysābūrī, Saḥ̄h Muslim, Kitāb al-Imārah, Bāb Man Qātala li Takūnu Kalimat Allah hiya al- 'Ulyā fahuwa fì Sabīl Allah (Qāhirah: Dār Ihyā' al-Kutub al-'Arabiyyah, 1374H), no. hadith 1904.

3 Al-Qaraḍāwi, Fiqh al-Jihād, 56. 
وكذلك لو نظرنا إلى القصد من تشريع الجهاد وهو دفع الشر وحماية

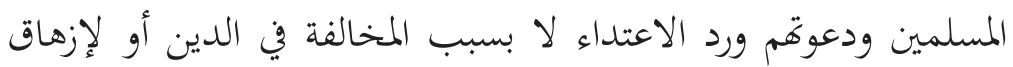

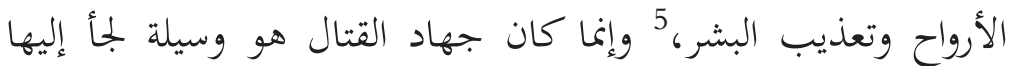

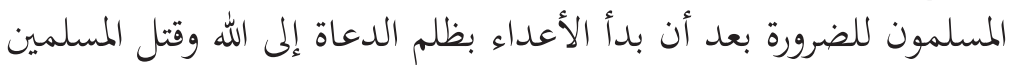

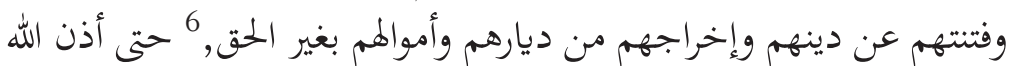

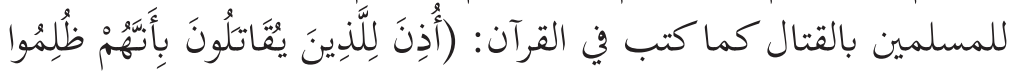

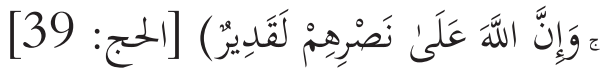

وقد صرح جمهور الفقهاء من المالكية والحنفية وأكثر الشافعية والحنابلة

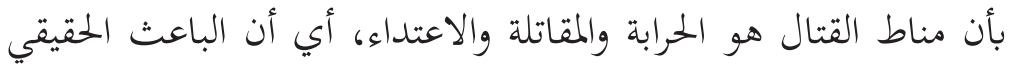

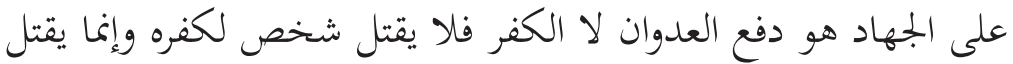

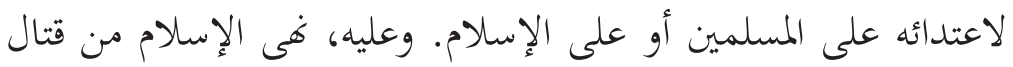

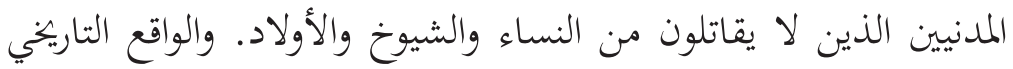
يؤيد هذا الاتحاه لأن المسلمين سواء ما قبل الهجرة أو بعدها هم هم من كانين كانوا المعتدى عليهم.

وبذلك اتضح لنا بأن الجهاد هو بذل الجهاد والكفاح بوسائل سلمية

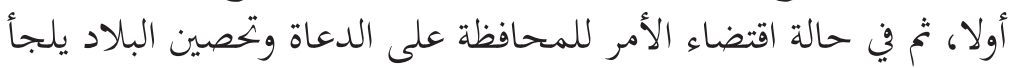

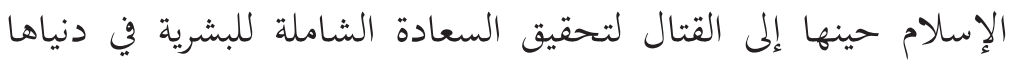
وأخراها، وكل جهد يبذل في هذا فهو في سبيل الله وحده ولإرضائه فقط

'Abdullah bin Bayah, al-Irhāb: al-Tashkhīṣ wa al-Hulūl (Riyāụ: Maktabah Malik Fahd, 2007), 127.

5 See for example the discussion on the maqāșid and the wasā'il of jihād in Shihāb al-Dīn al-Qarāfì, Anwār al-Burūq fì Anwā' al-Furūq, vol. 2 (n.p: n.d), 32-33.

6 Wahbah al-Zuhaylī, al- 'Alāqāt al-Duwaliyyah fì al-Islām (Dimashq: Dār al-Maktabī, 2000), 25.

Ibid, 26-28. 
دون أن يشوب نوايا المسلمين نزعة مادية أو هوى شخصي أو تسلط على

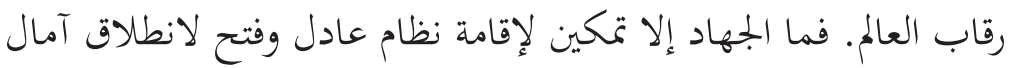
البشرية الفطرية وتقرير الحرية الطبيعية التي تتطلع إلى العقيدة السليمة. ولذلك فإن المفهوم الصحيح للجهاد هو مفهوم التوسط والاعتدال

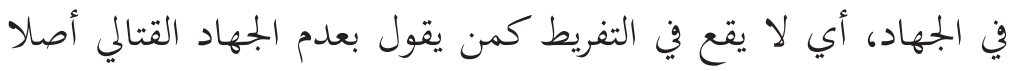

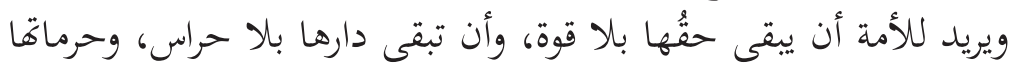

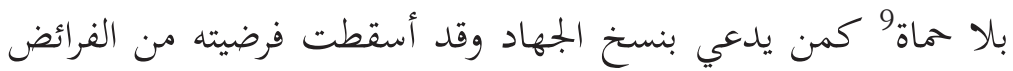

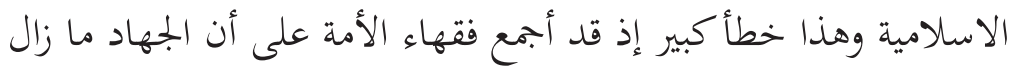

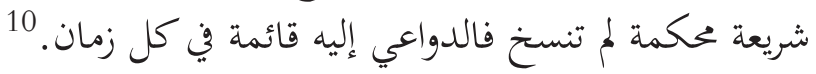

ولا يقع في الإفراط كفئة من الفئات التي فهمت الجهاد على أنه قتال

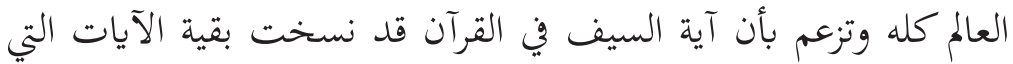

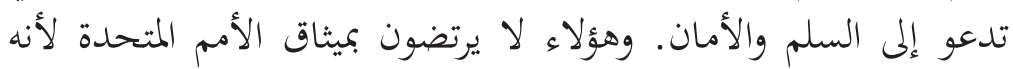

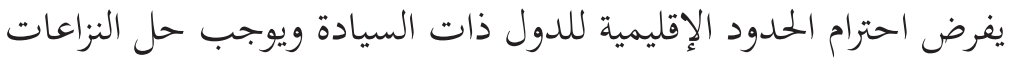

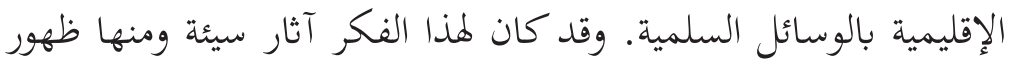

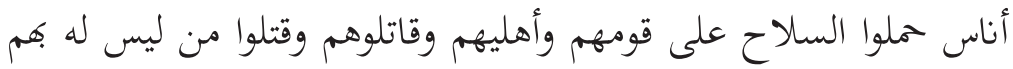

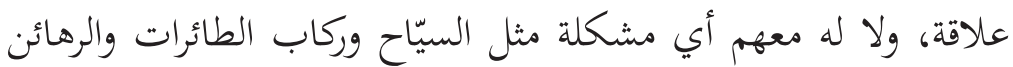

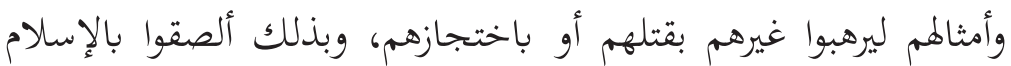

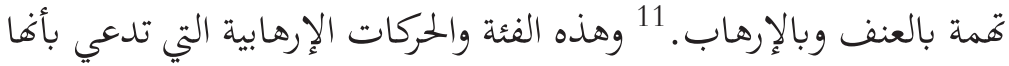
تجاهد في سبيل الله وتتحدث بالعندمابـ الإسلام هي التي سنركز إليها في هذا البحث, إن شاء الله.

Wahbah al-Zuhaylī, Athār al-Harb fì al-Fiqh al-Islāmī: Dirāsah Muqāranah (Dimashq: Dār al-Fikr, 1998), 35.

Al-Qaraḍ̄wi, Fiqh al-Jihād, 27.

10 Al-Zuhaylī, Athār al-Harb, 95.

11 Al-Qaraḍāwi, Fiqh al-Jihād, 25-28. 


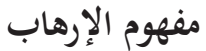

إن كلمة ( إرهاب ) كلمة عربية في الأصل، فكلمة ( إرهاب ) مصدر إبرد

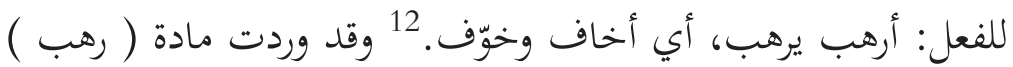

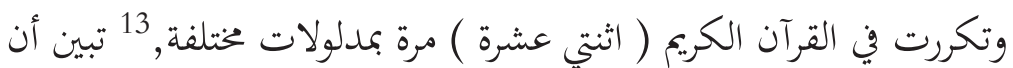

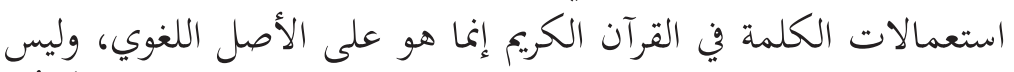

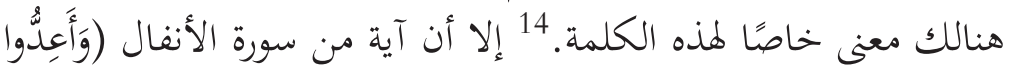

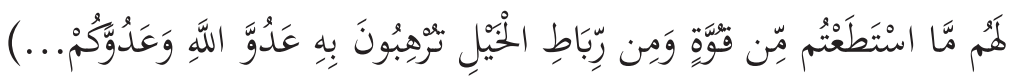

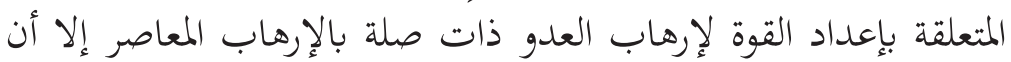

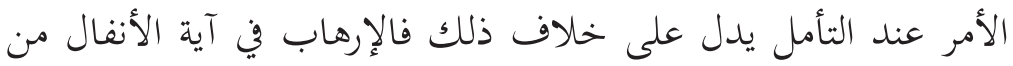

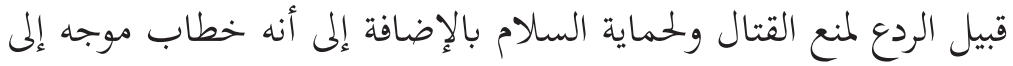
الدولة المسلمة وليس لأفراد ولا لجماعات. 15

ولذلك لا بد لنا أن نبحث عن معنى الإرهاب من منظور الاصطلاح

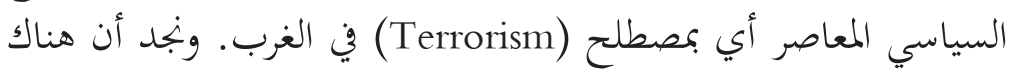

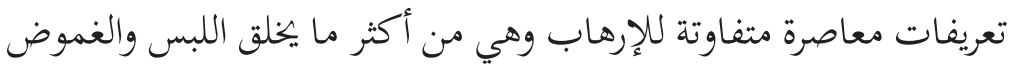

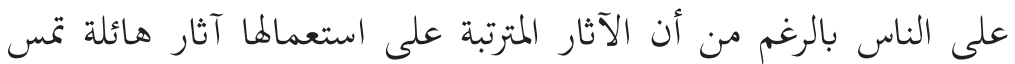

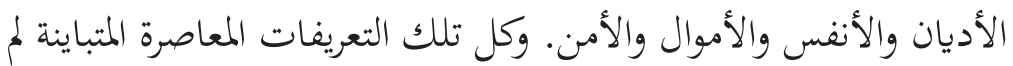

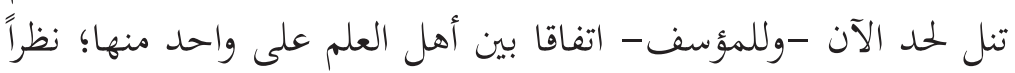

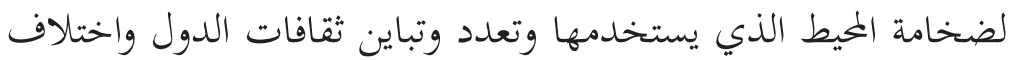

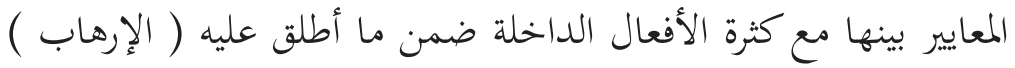
وهي أفعال تختلف دوافعها وبواعثها, وتفسيراهتها. 16

وقد ظهر مصطلح الإرهاب (Terrorism) منذ عام 1798م في وني

Ibid, 60 .

Bin Bayah, al-Irhāb: al-Tashkhīș, 23-25.

"Abd al-Raḥman al-Luwayḥiq, "al-Islam wa al-Irhāb Mutanāqị̣ān," Dawrah Tadribiyyah li Mukāfaḥati al-Irhāb, Tunis, 2008, 5.

15 Bin Bayah, al-Irhāb: al-Tashkhīs, 25.

16 Al-Luwayhịiq, al-Islam wa al-Irhāb, 6. 
ملحق الأكاديمية الفرنسية لوصف حكومة الثورة الفرنسية التي كانت ترهب

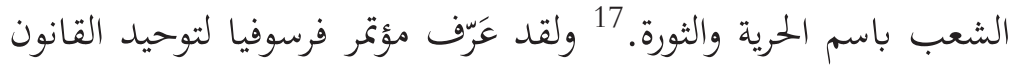

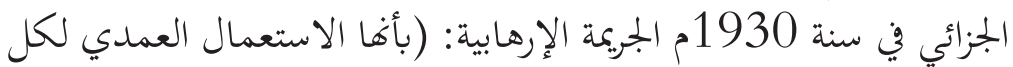

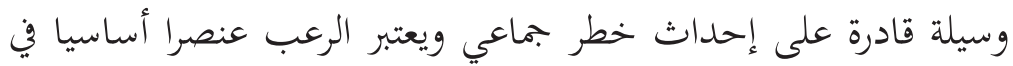

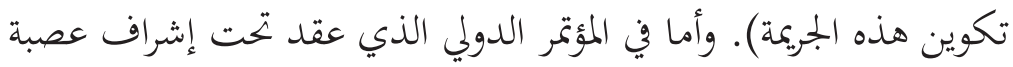

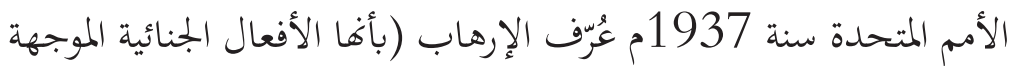

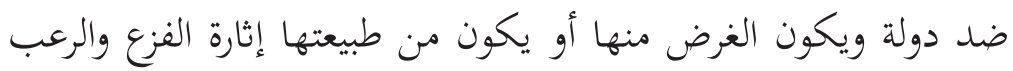

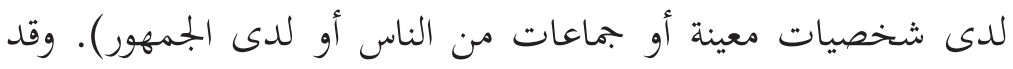

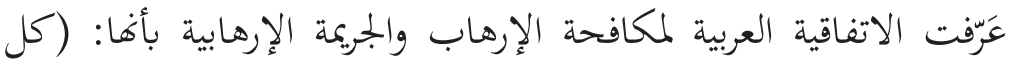

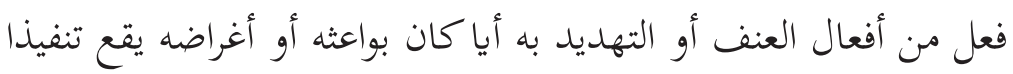

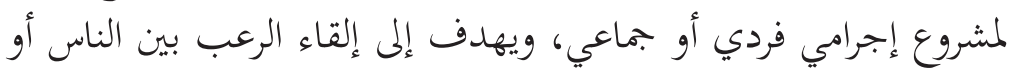

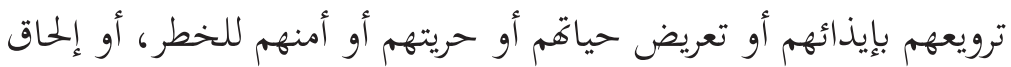

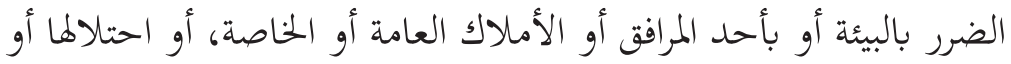
الاستلاء عليها، أو تعريض أحد الموارد الوطنية للخطر). 18

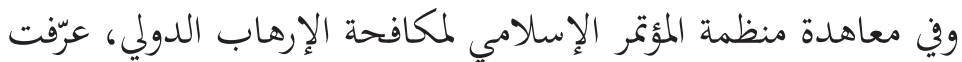

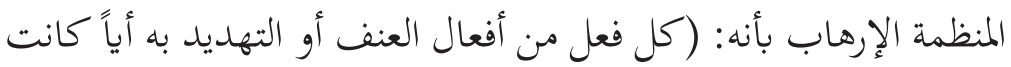

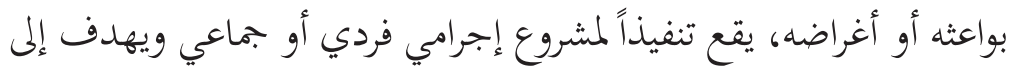

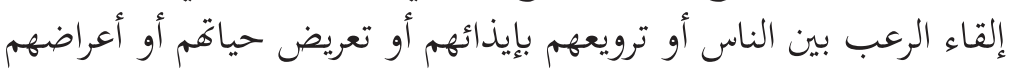

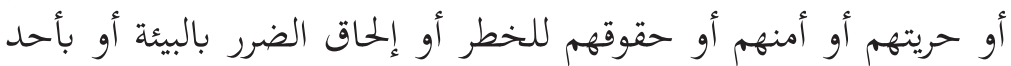

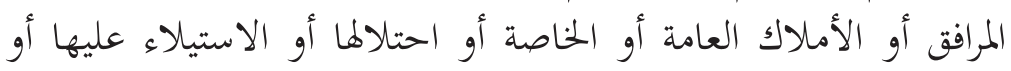

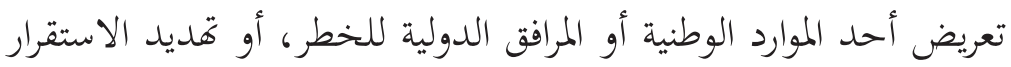

Bin Bayah, al-Irhāb: al-Tashkhīș, 25.

18 Haytham 'Abd al-Salām, Mafhūm al-Irhāb fì al-Sharī'ah alIslāmiyyah (Bayrūt: Dār al-Kutub al-'Ilmiyyah, 2005), 25-27. 
أو السلامة الإقليمية أو الوحدة السياسية أو سيادة الدول المستقلة).19

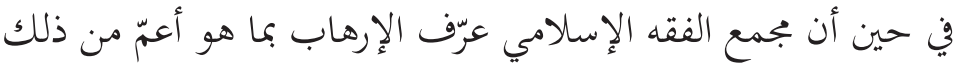

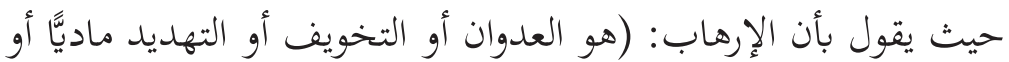

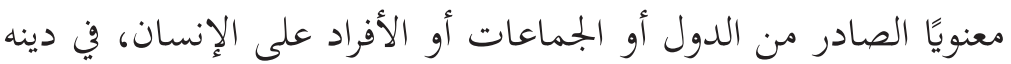

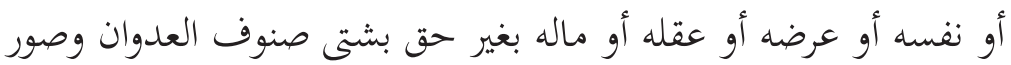
الإفساد في الأرض).

وهكذا، وفي رأي الباحثَين، فإن مصطلح 》الإرهابش الذي هو شائع

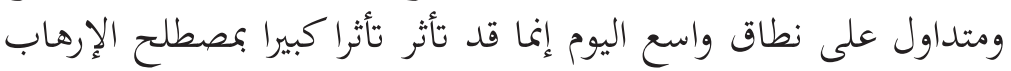

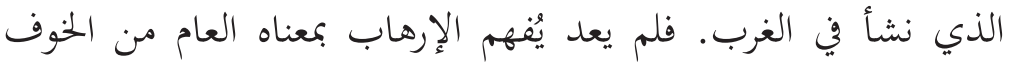

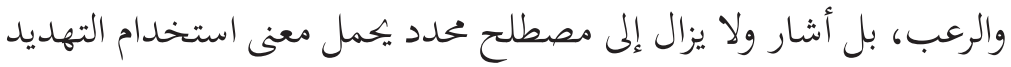

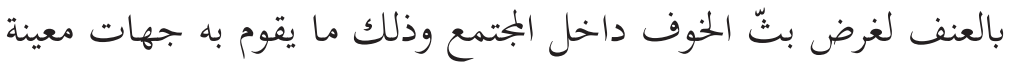
من أجل تحقيق أهدافهم السياسية المنشودة.

إن العلاقة بين الإرهاب والإنسان قديمة قِدم البشرية فقد وجدات

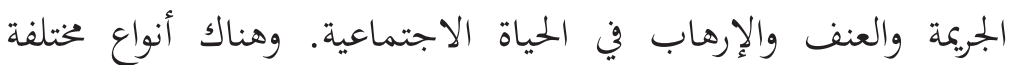

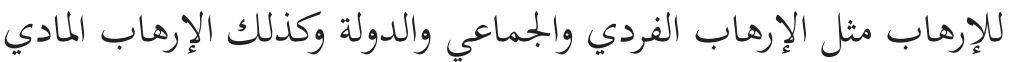

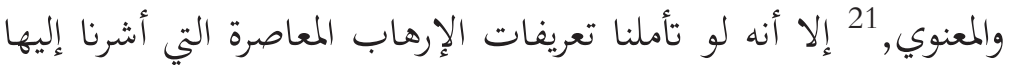
آنفا لوجدنا بأنه منذ هاية القرن الثامن عشر أصبح مصطلح التهابح الإرهاب

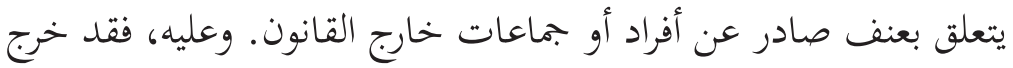
من دائرة المناقشة أي عملية إرهابية ارتكبتها الدولة مثل ما فعلتهاد إعات الولايات

19 See Melinda Negrón-Gonzales, "Counterterrorism Resolutions and Initiatives by Regional Institutions: Organization of Islamic Cooperation," International Human Rights (2019): 8.

20 Majma“ al-Fiqh al-Islāmī al-Dawlī, "Qarār bi sha'n Mawqif al-Islām min al-Ghuluw wa al-Tațarruf wa al-Irhāb," Offical Website of the International Islamic Fiqh Academy, available at: https://www.iifaaifi.org/ar/2206.html.

21 Haytham, Mafhüm al-Irhāb , 149-155. 
المتحدة الأمريكية في فيتنام وأفغانستان والعراق وغيرها من الدول وكذلك

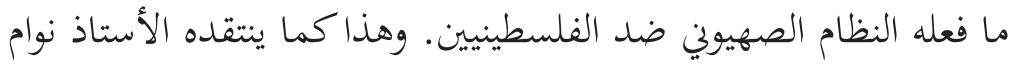

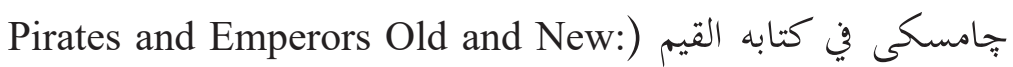
${ }^{22}$. (International Terrorism in the Real World

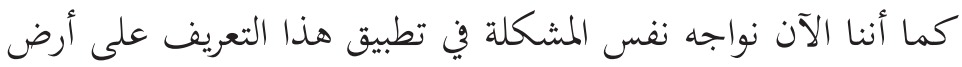

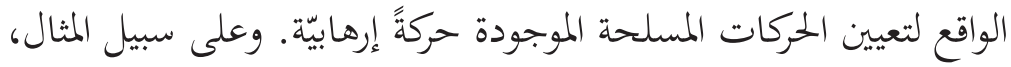

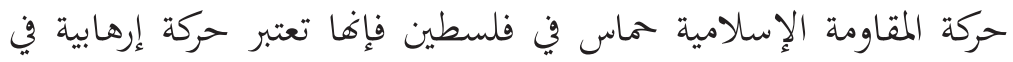

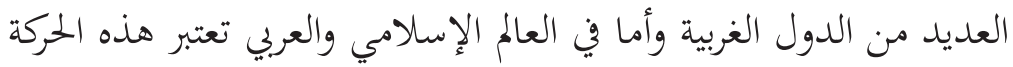

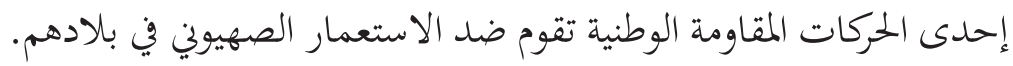

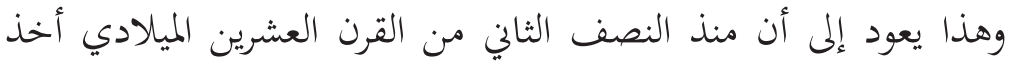

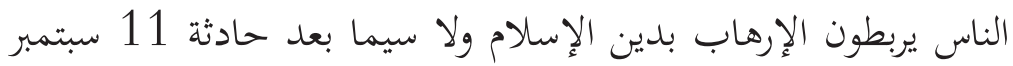

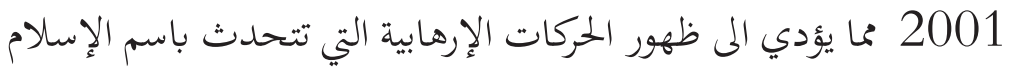

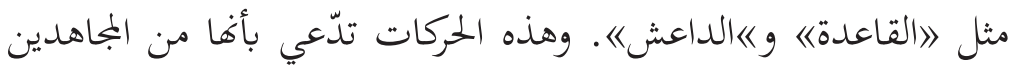

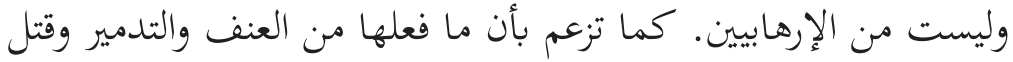

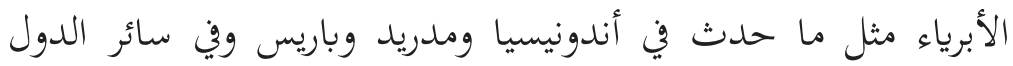
العربية هي كلها من الجهاد المشروع في الإسلام.

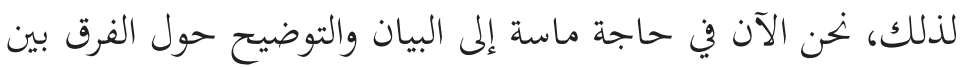
الجهاد المشروع والإرهاب المذموم في منظور الإسلامي.

\section{الفرق بين الجهاد والإرهاب}

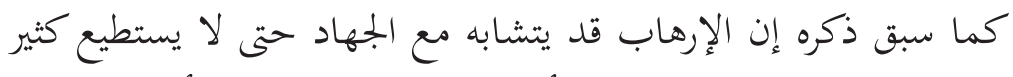

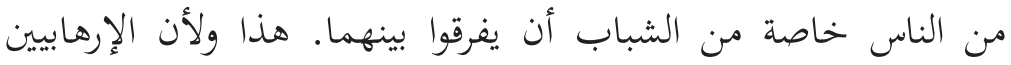

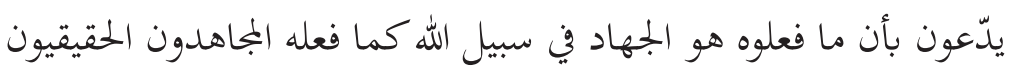

22 See for more details: Noam Chomsky, Pirates and Emperors, Old and New: International Terrorism in the Real World (London: Pluto Press, 2002). 
فالمجاهدون - كما نراهم في الصور - يصلّون ويقرؤون القرآن ويؤدّون سائر

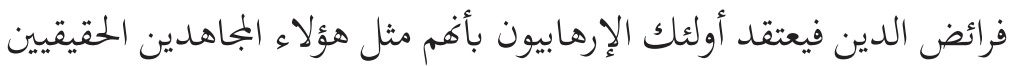

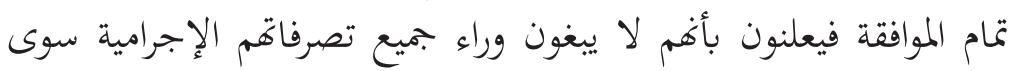
نصرا للإسلام وتمنيا للشهادة والجنة.

ولكن كل هذه التشاهات هي في الظواهر فقط فلو تأملنا تأملا عميقا

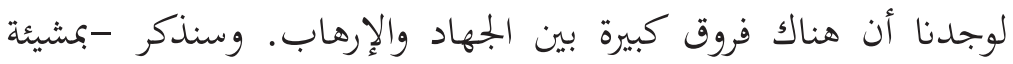

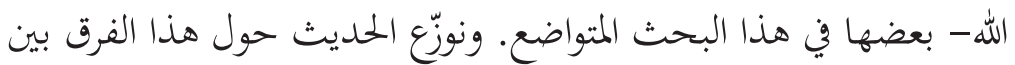

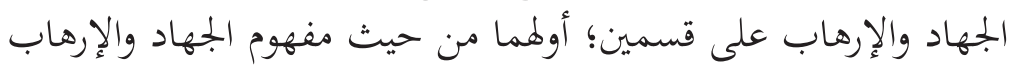

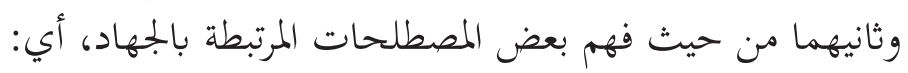

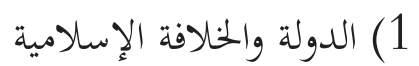

2) تقسيم العالم إلى دار الإسلام ودار الحرب 3) الولاء والبراء والتكفير

\section{الأول: الفرق بين مفهوم الجهاد ومفهوم الإرهاب}

بعد أن بحثنا في كلا المصطلحين الجهاد والإرهاب آنفا، اتضّح لنا بأن الإن هناك فرق كبير بين الجهاد والإرهاب في مفهومهما:

أولا، إن مفهوم الجهاد أوسع من الإرهاب فالجهاد لا يقصد الستخدام

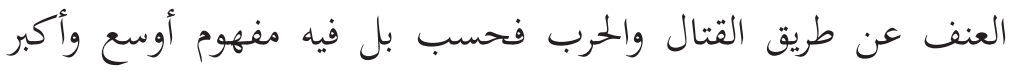

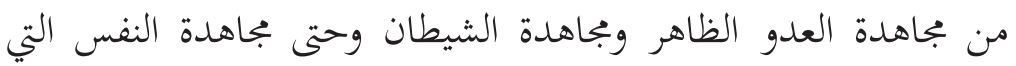

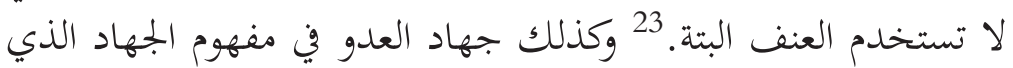

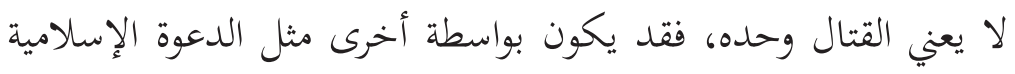

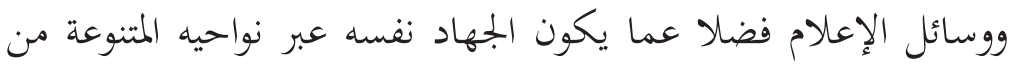

23 Bin Bayah, al-Irhāb: al-Tashkhīs, 125. 
الجهاد العلمي والاجتماعي والاقتصادي والتربوي والصحي والبيئي. 24 أما

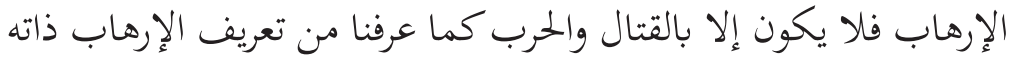

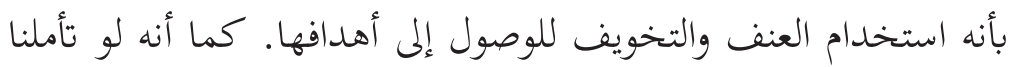

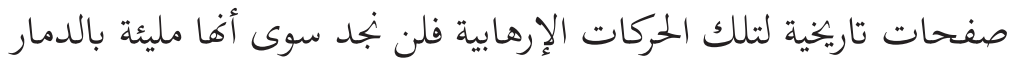
وسفك دماء الأبرياء تحقيقا لأهدافها.

ثانيا، من ناحية إصدار الأمر والإذن بالقتال والهجوم؛ فإِن المجاهد

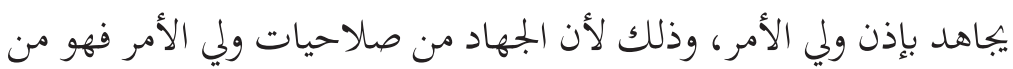

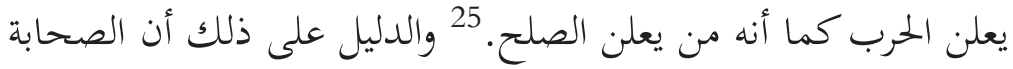
-رضي الله عنهم- كانوا لا يجاهدون إلا بأمر الرسول -صلى الهي الله عليه

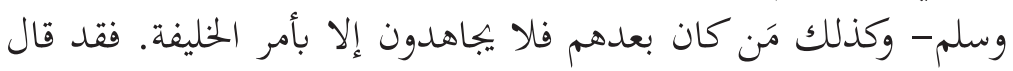

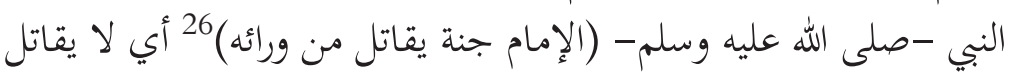

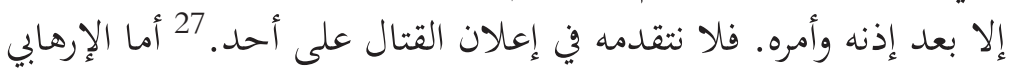

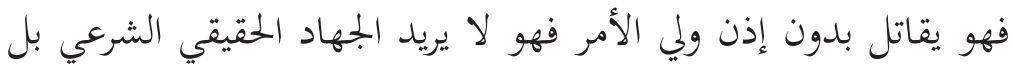

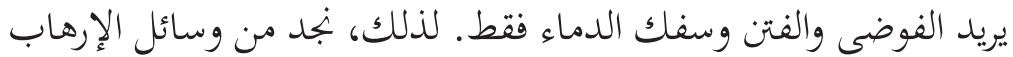

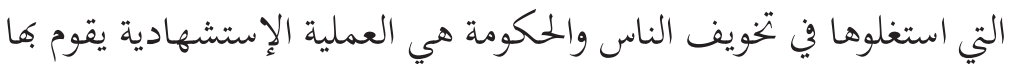

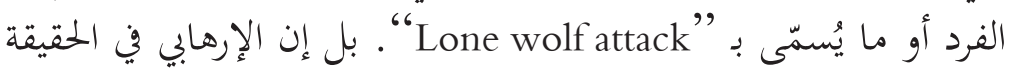
والواقع بتحه يكفّر ولي أمر المسلمين ويقاتله فبدلا من أن يقاتل تحت رايته، يقاتله ويسفك دماء جنوده ورعيته. 28

ثالثا، على مستوى العدو؛ فإن الجماهد يقاتل العدو من الكفار

24 Al-Qaraḍāwi, Fiqh al-Jihād, 231-240.

25 Bin Bayah, al-Irhāb: al-Tashkhīṣ, 131; See also Wael B. Hallaq, The Impossible State: Islam, Politics, and Modernity's Moral Predicament (New York: Columbia University Press, 2013), 94-95.

26 Muslim, Saḥ̄ḥ Muslim, Kitāb al-Imārah, Bāb fì al-Imām Idhā Amara bi Taqwā Allah wa 'Adala Kāna lahu Ajr, hadith no. 1841.

27 Al-Qaraḍāwi, Fiqh al-Jihād, 684.

28 Islamic State of Iraq and the Levant (ISIL), "DABIQ," vol. 2, Al Hayat Media Center, 2014. 


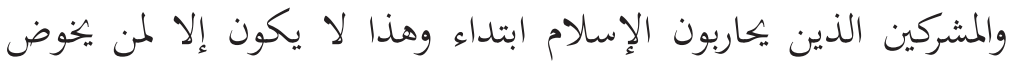

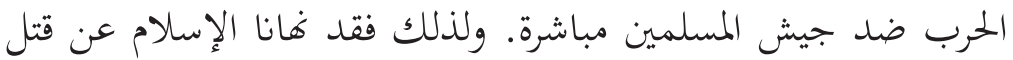

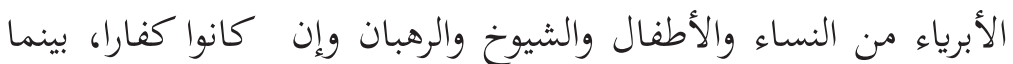

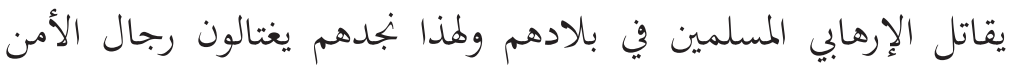

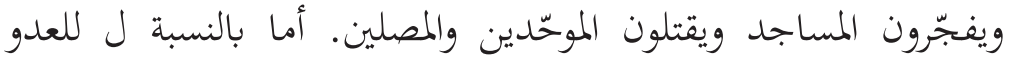

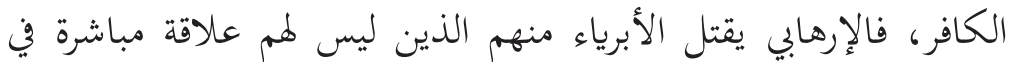

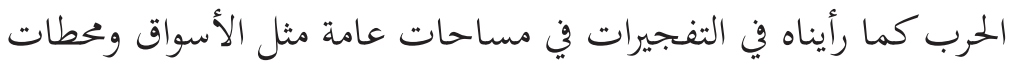
القطار والفنادق التي لا يتواجد فيها إلا الأبرياء من المدنيين.

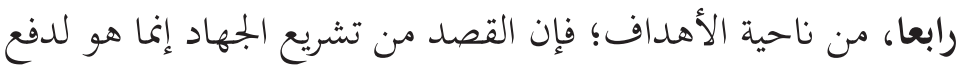

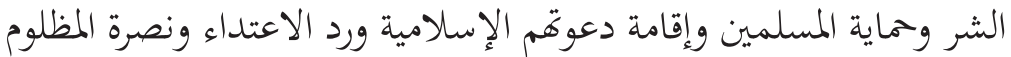

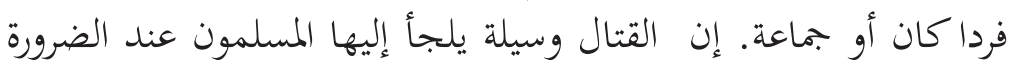
فقط لأن الأصل في العلاقة بين المسلمين وغيرهم هو السلاعلام والأمان.

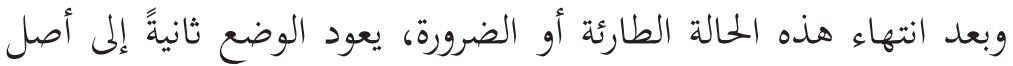

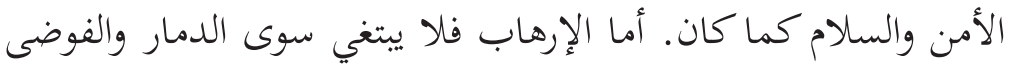

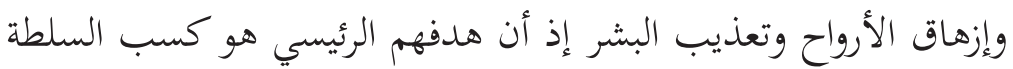

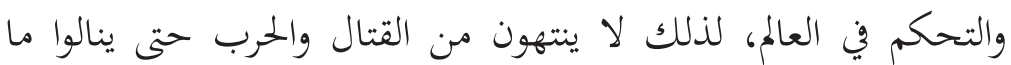
يبنغونه.

وبهذا، يتضح لنا أن الجهاد أمر يشرعه الدين لحث المسلمين على السعي

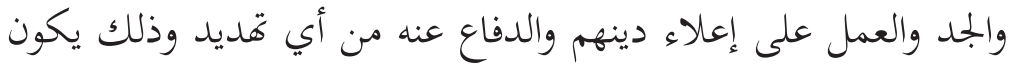

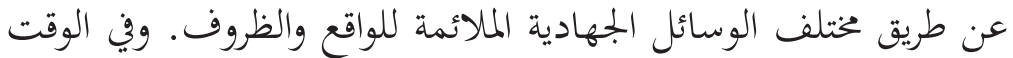

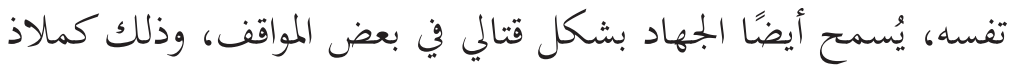

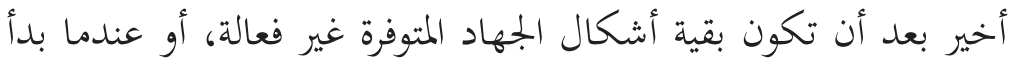

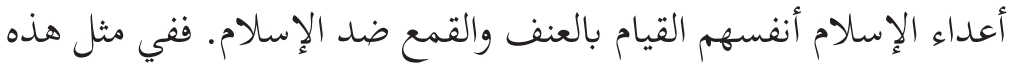

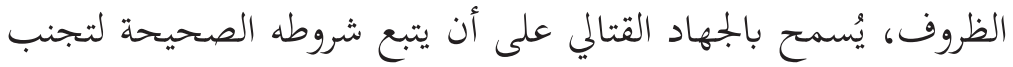

29 Al-Zuhaylī, al- 'Alāqāt al-Duwaliyyah, 25-32. 
حدوث أي ضرر أكبر. في حين أن الإسلام لا يشرع أبدا الإرهاب تحت

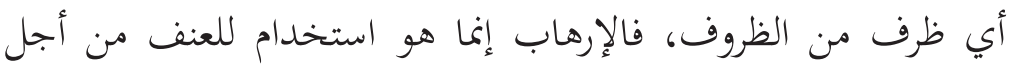

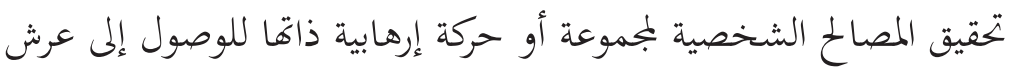

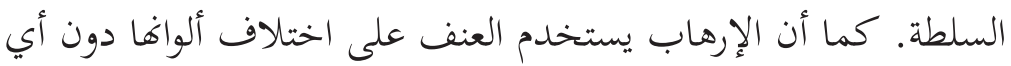

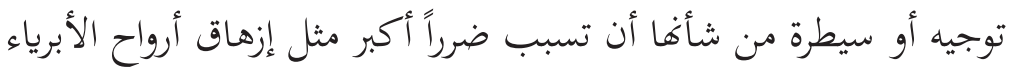

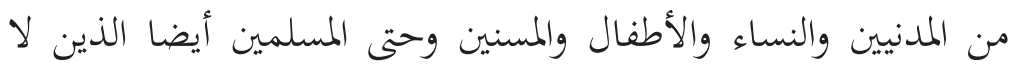
يخوضون بشكل مباشر في حركم.

الثاني: الفرق بين فكرة الجهاد وفكرة الإرهاب في فهم بعض المصطلحات

( ) الدولة والخلافة الإسلامية

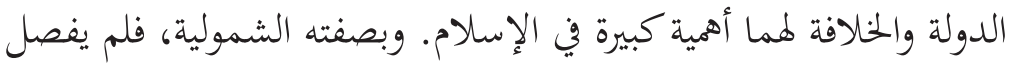

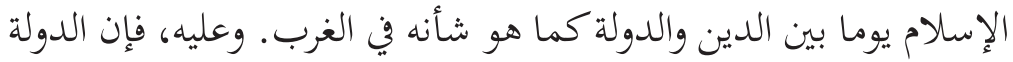

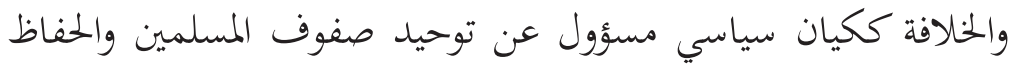

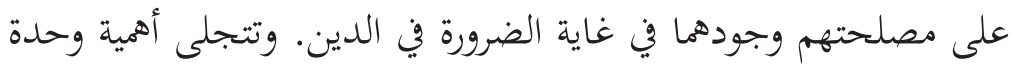

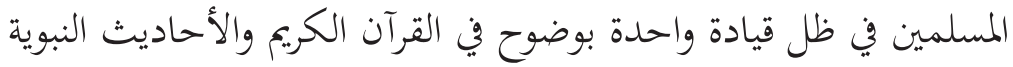

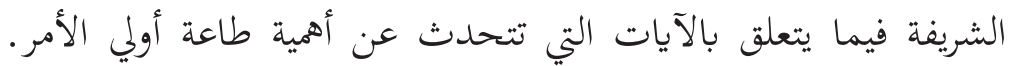

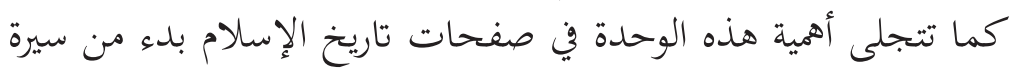

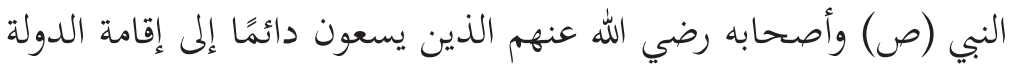

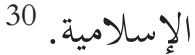

ومع ذلك ، فإن صورة الدولة الإسلامية التي ينبغي تأسيسها ليست

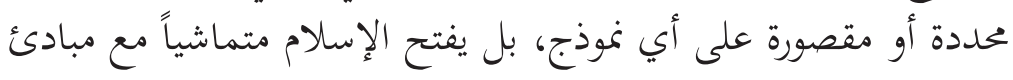
السياسة الشرعية المرنة مساحة واسعة لبناء دولة إسلامية تتوافق مع البيئة

30 For more discussion on this textual evidences on dawlah and khiläfah in Islam, see Yūsuf al-Qaraḍāwi, Min Fiqh al-Dawlah fì al-Islām (Qāhirah: Dār al-Shurūq, 1997), 13-21. 
المثغيرة والظروف الحالية، طالما أها تقوم على المبادئ التي وضعها الإسلام.

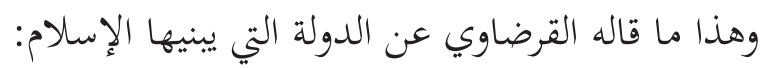

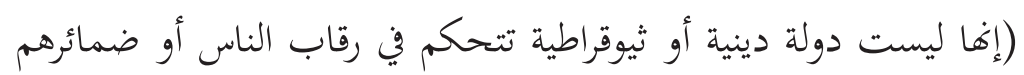

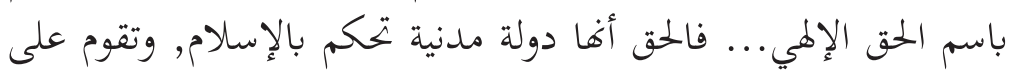
البيعة والشورى, ويختار رجالها من كل قوي أمين, حفيظ عليم.... أما فكرة الحلافة والدولة الإسلامية التي هي أهم الأيديولوجيات بالنسبة

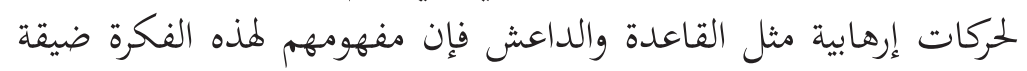

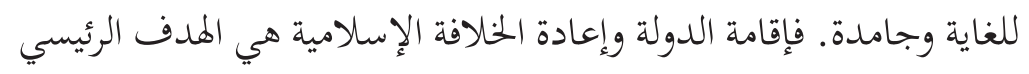

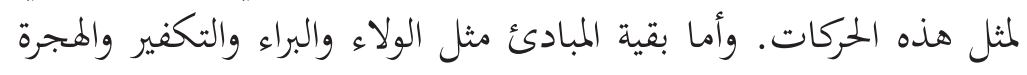

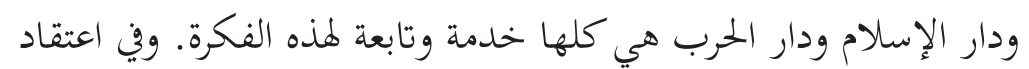

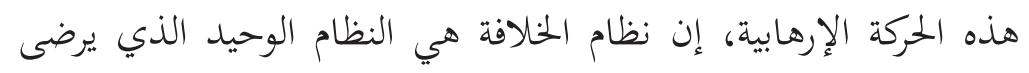

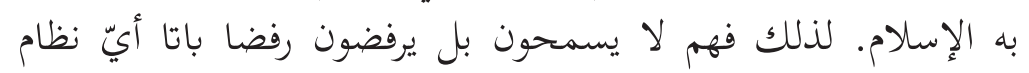

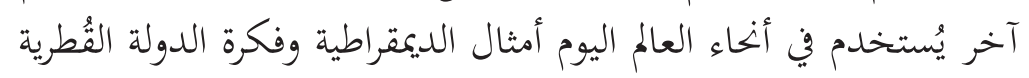

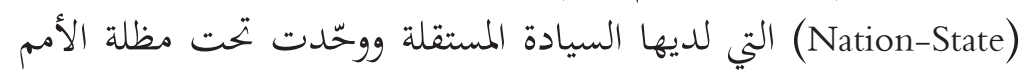

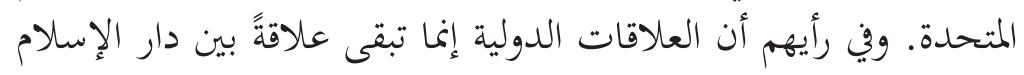

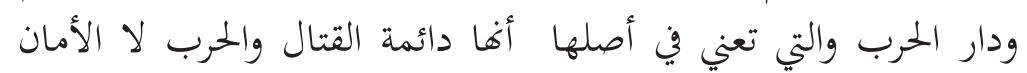
والسلام.

وهذا واضح في هياكل هذه الحركات الإرهابية التي بها شبكة عالمية تتجاوز

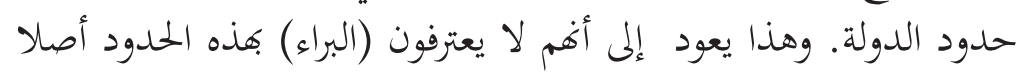

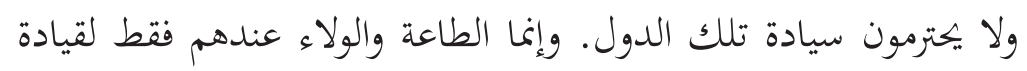

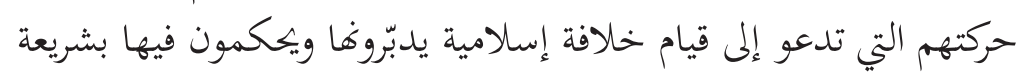
الإسلام على شكل كليّ وشامل. 33

31 Ibid., 30.

32 "DABIQ," vol. 1.

33 Abū Muṣ'ab al-Sūrī, Da'wah al-Muqāwamah al-Islāmiyyah al'Ālamiyyah (n.p.: 2004). 
وي المقابل، فقد دعا علماء المسلمين والمفكرين المعاصرين إلى الفهم

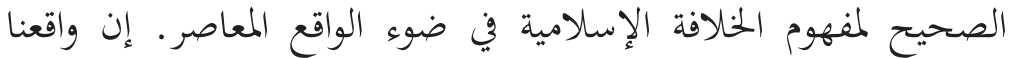
اليوم والعالم الذي نعيش فيه شيء لا نستطيع أن ننكره ولا نغيره بين

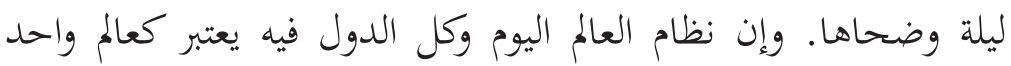

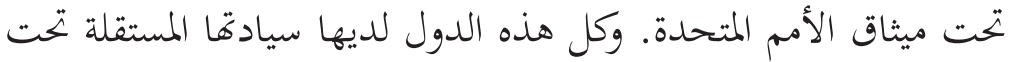

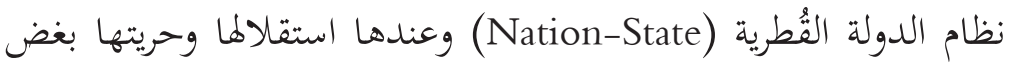

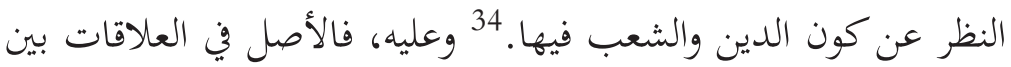

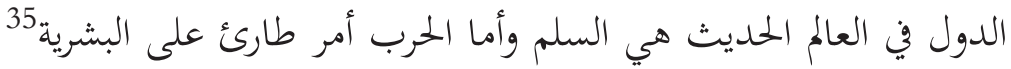

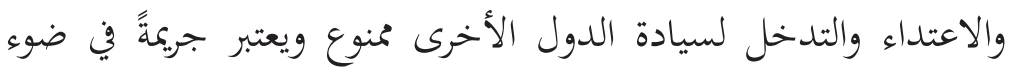

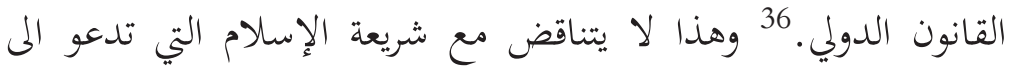

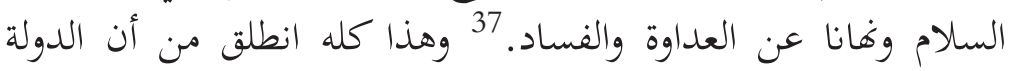

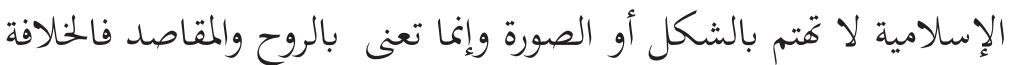
في الإسلام أمر مصلحي لا تعبدي كما قال العلامة عبد الله بن بيه. 38 ولذلك لا نجد أي صراع أو خلاف بين الإسياسة الشرعية وبين الروح الديمقراطية الأصيلة.

\section{2) تقسيم العالم إلى دار الإسلام ودار الحرب}

إن الإرهابيين ما زالوا ينظرون للعالم في انقسامه إلى صنفين فحسب (dichotomy)

Al-Zuhaylī, al- 'Alāqāt al-Duwaliyyah, 15.

Al-Zuhaylī, al-'Alāqāt al-Duwaliyyah, 94.

Al-Qaraḍāwi, Fiqh al-Jihād, 12.

37 'Abdullah bin Bayah, "al-Dawlah al-Wațaniyyah fì al-Mujtama'at al-Muslimah," Multaqā al-Thālith li Muntadā Ta'ziz al-Silm, Abu Zabī, 2016, 6; "Marrakesh Declaration," 2016, http://www. marrakeshdeclaration.org.

38 Bin Bayah, "al-Dawlah al-Wațaniyyah," 15.

39 Yūsuf al-Qaraḍāwi, Min Fiqh al-Dawlah fì al-Islām (Qāhirah: Dār al-Shurūq, 1997),36 . 
فقهيا قديما حول مشروعية الجهاد. فهم يرون بأن آية السيف في القرآن

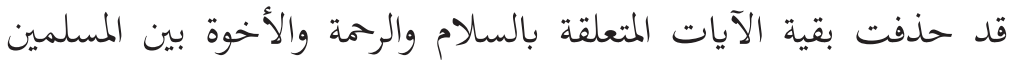

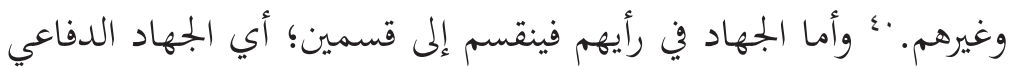

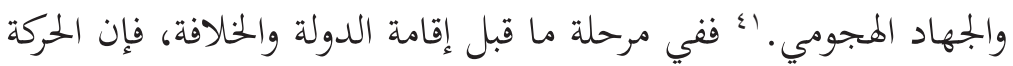

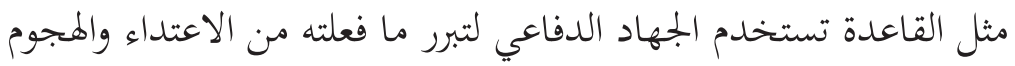

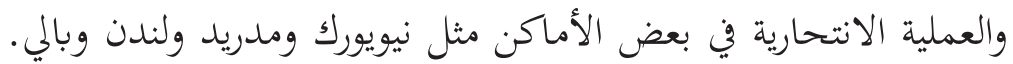

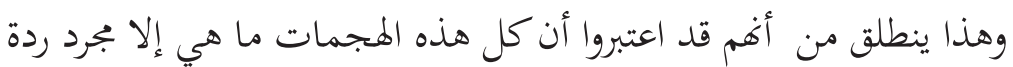

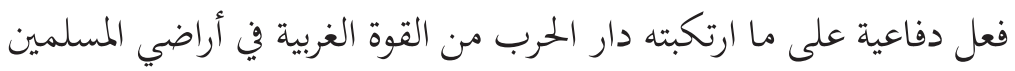

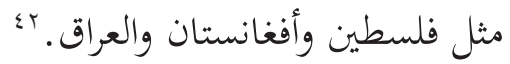

وأما بالنسبة لمرحلة ما بعد أن يتم تأسيس الدولة والخلافة الإسلامية

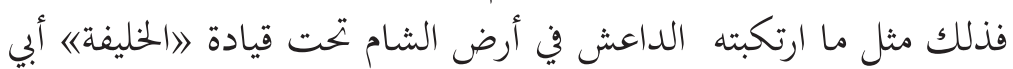

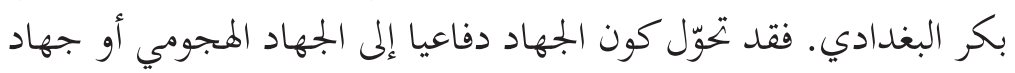

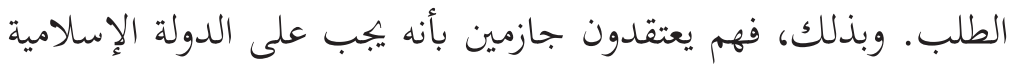

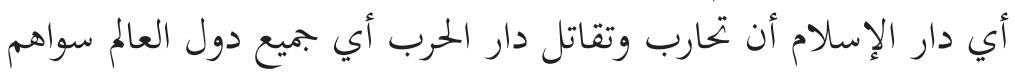

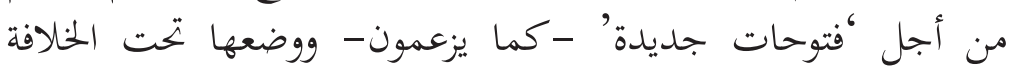

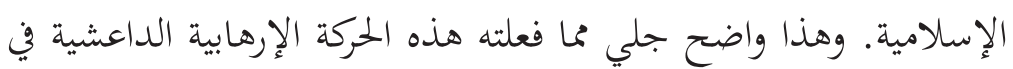

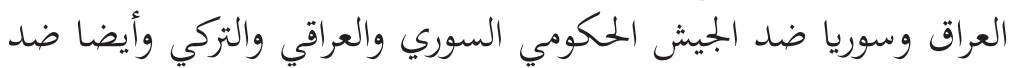

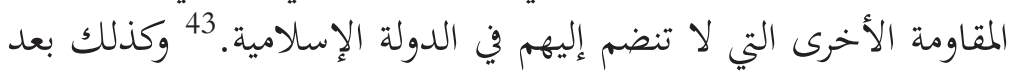

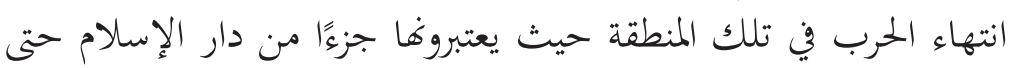

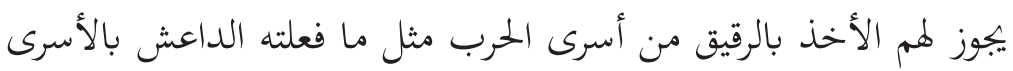
من نساء اليزيدية.

"DABIQ," vol. 4.

41 al-Sūrī, Da 'wah al-Muqāwamah.

42 Aymān al-Ẓawāhirī, al-Tabri'ah: Risālah fĩ Tabri'ah Ummah alQalam wa al-Sayf (n.p.: 2008).

43 DABIQ 4, 2014.

44 DABIQ 4, 2014. 
أما رأي العلماء المعاصرين فقالوا متفقين بل بالإجماع على أن الدولة

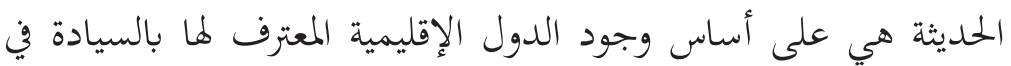

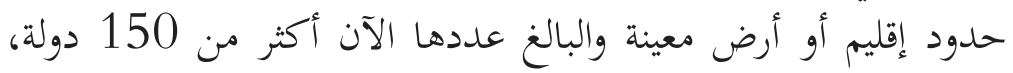

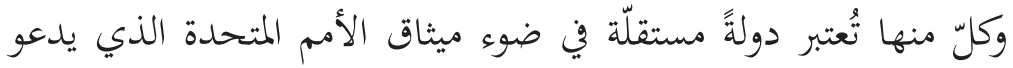

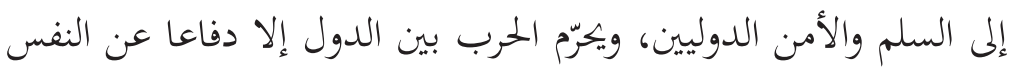

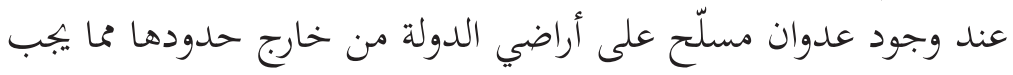

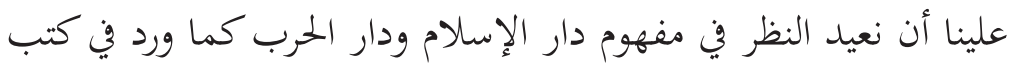

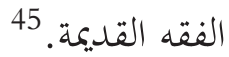

أما بالنسبة لتقسيم المجتهدين السابقين للعالم إلى الدارين أي دار

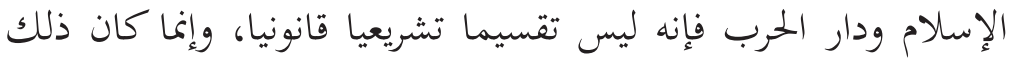

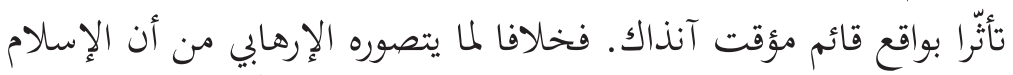

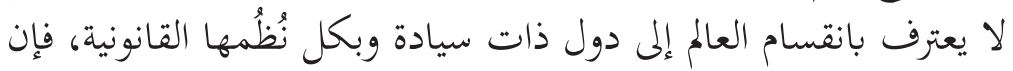

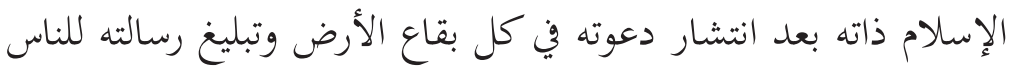

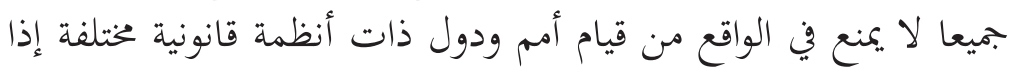

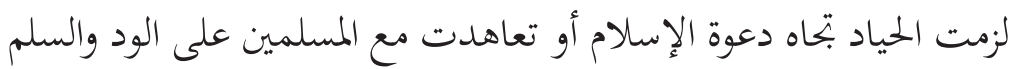

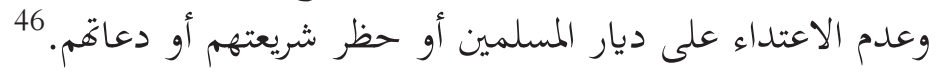

وقد وجدنا نصوص الفقهاء شاهدة على أن قضية الخلافة لا ترتبط

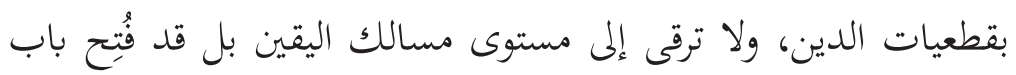

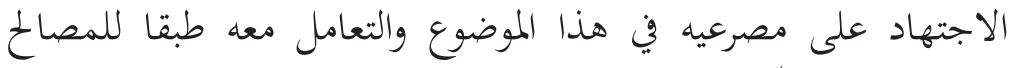

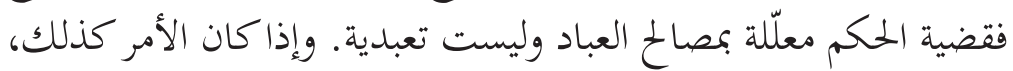

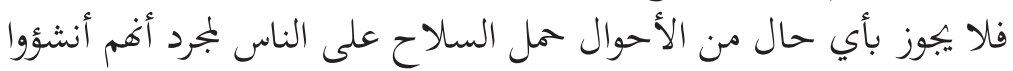

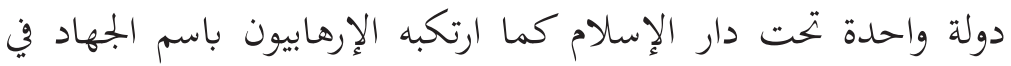
سبيل الله. 47

\begin{tabular}{l}
\hline Al-Zuhaylī, al- 'Alāqāt al-Duwaliyyah, 17. \\
${ }_{46}$ Ibid, 18. \\
${ }_{47}$ Bin Bayah, "al-Dawlah al-Wațaniyyah," 16-17.
\end{tabular} 
3) الولاء والبراء وفكرة التكفير

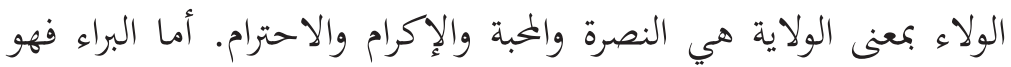

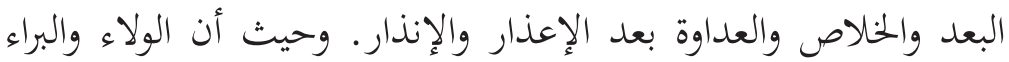

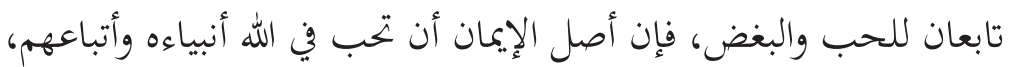
وتبغض في الله أعداء رسله.

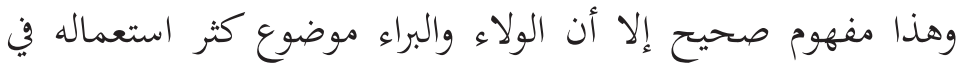

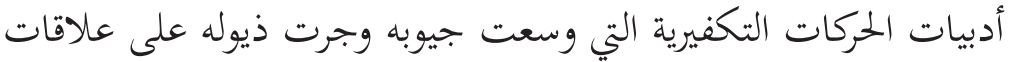

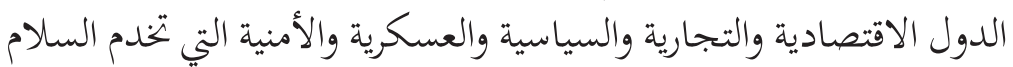

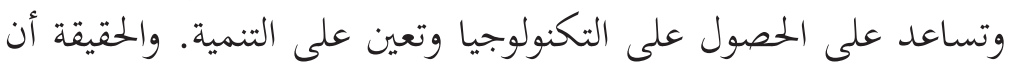

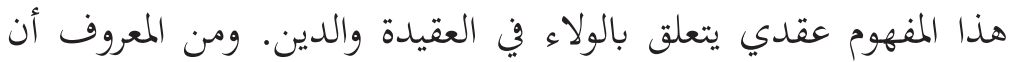

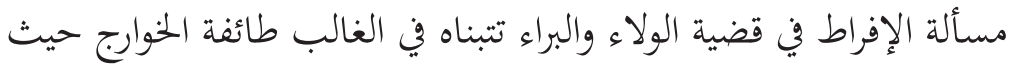
تبنى عليها مذهبها.

وهذا ما فعله الإرهابيون من القاعدة والداعش حين يكفّرون الناس

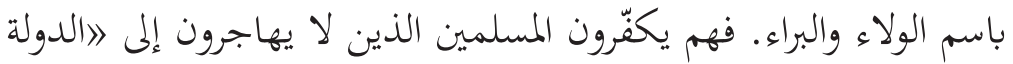

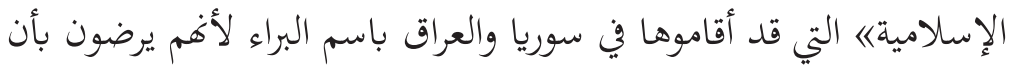

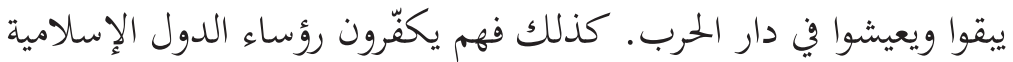

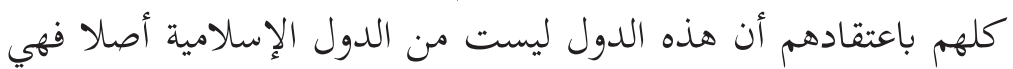

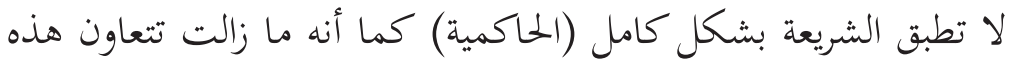

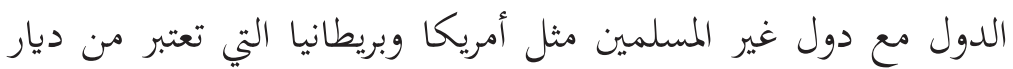

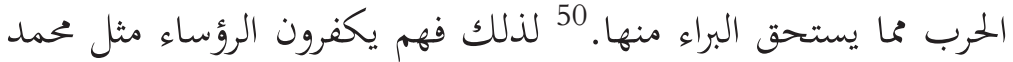

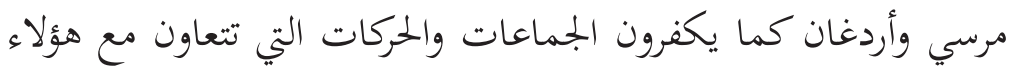

$\overline{48}$ Muhammad bin Sa 'īd al-Qahțānī, al-Walā’ wa al-Barā’ fì al-Islām (Makkah: Dār al-Tayyibah, 1413H), 90.

49 Bin Bayah, al-Irhāb: al-Tashkhīs, 137.

50 “DABIQ," vol. 3. 
مثل جماعة الإخوان المسلمين وكذلك الجيش والشرطة لكل هذه البلاد. 51 وهذا من الواضح خطأ كبير وضلال بيّن فالتكفير في الإسلام ليس كما

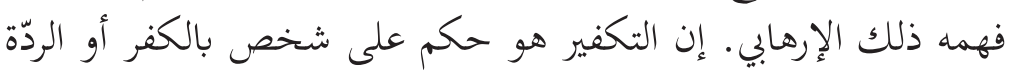

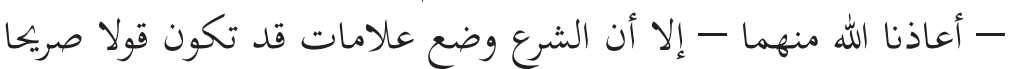

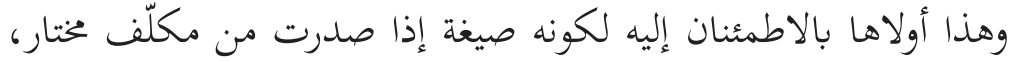

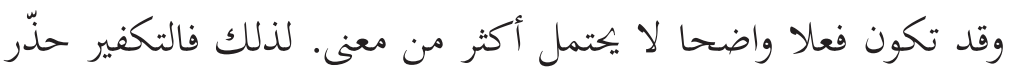

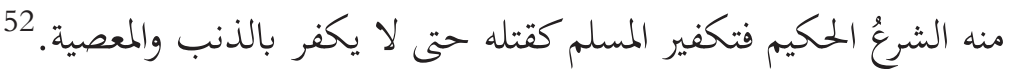

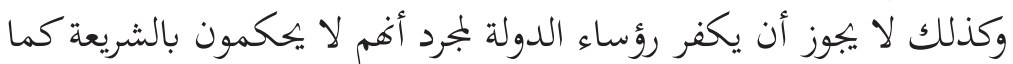

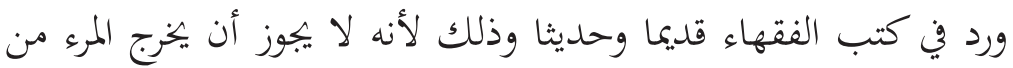

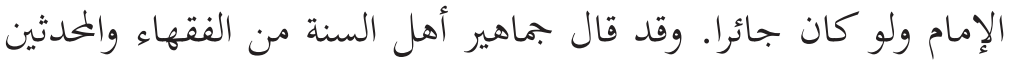

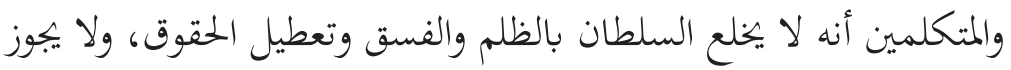
بذلك الخروج عليه بل يجب وعظه. 53

خاتمة

والخلاصة إن الإسالام دين شامل يخدم مصالح الناس كلها في الدنيا

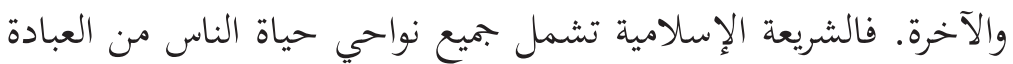

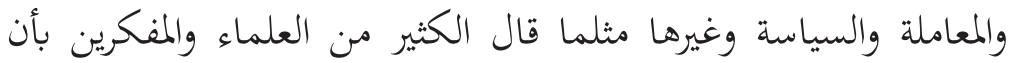

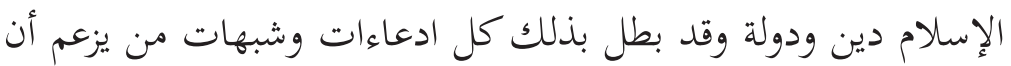

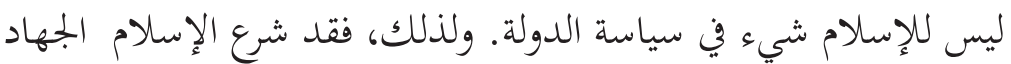

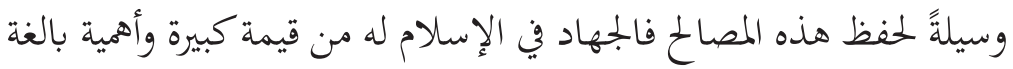

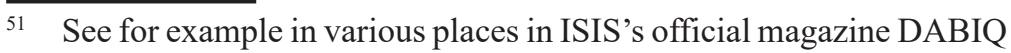
where they openly excommunicate (takfir) Muslim leaders and the Muslim Brotherhood, and also see Muhammad Haniff Hassan, "The Danger of Takfir (Excommunication): Exposing IS' Takfiri Ideology," Counter Terrorist Trends and Analyses 9, no. 4 (2017): 3-12.

52 Bin Bayah, al-Irhāb: al-Tashkhịs, 141.

53 Ibid, 35 . 
في الحفاظ على هوية الأمة والدفاع عن كياها المادي والمعنوي وعن أرضها

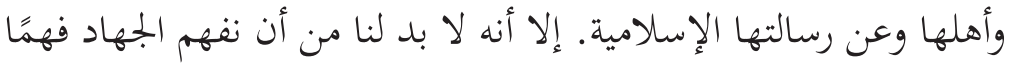

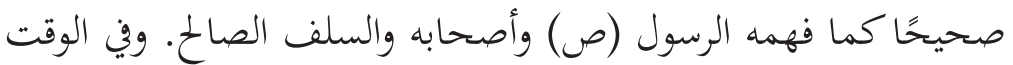
ذاته، فلا بد أن نعيش ونعايش زماننا ونتعامل مع الواقع المعاصر انطلاقًا

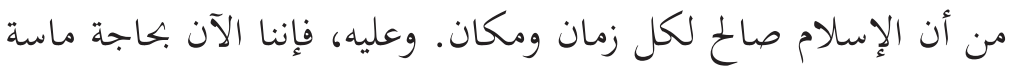

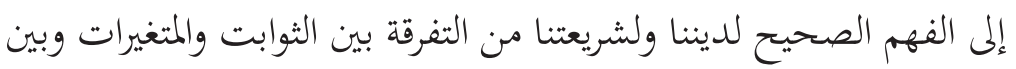

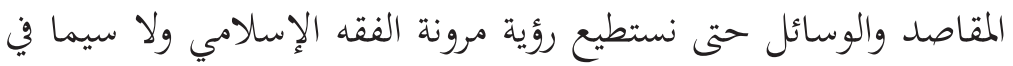

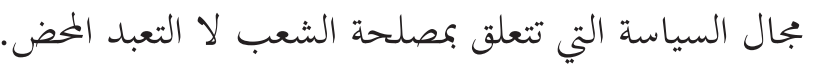

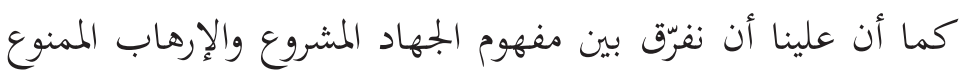

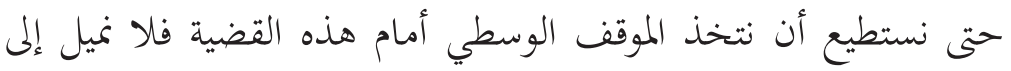

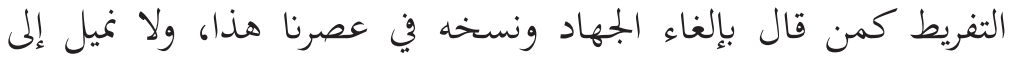

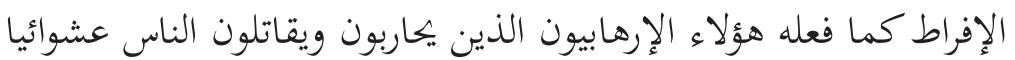

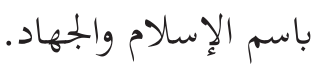

ومن خلال هذا البحث اتضّح لنا بأن هناك فرق كبير بين الجهاد

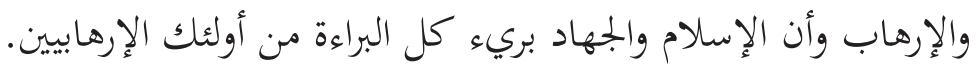

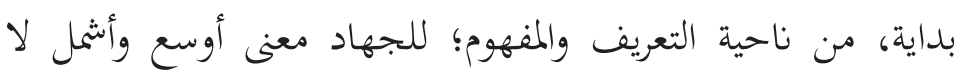

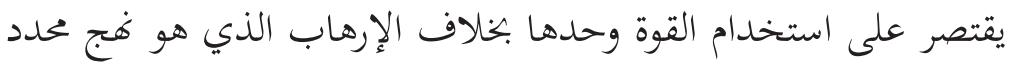

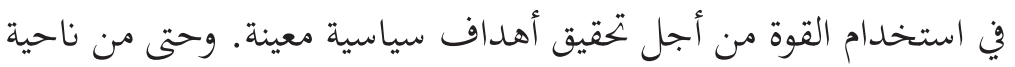

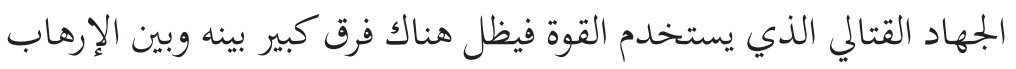

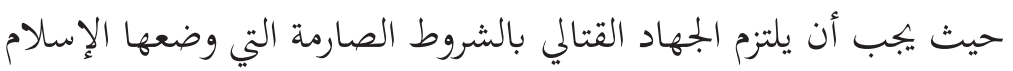

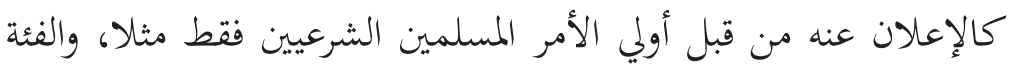

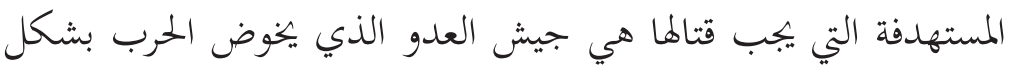

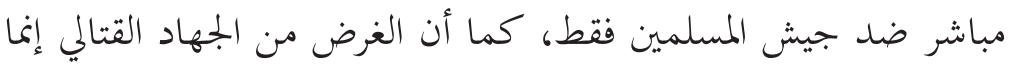

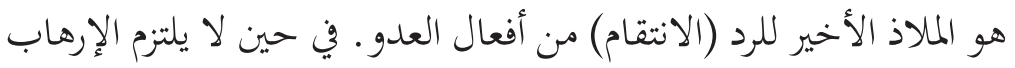


يومًا بهذه الشروط التي غالبًا ما تسبب ضررًا أكبر من تصرفاقم وأفعالهم

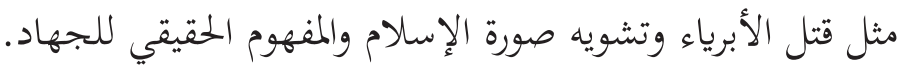

أضف إلى ذلك، فهناك خطأ جسيم لدى هذه الحركات الإرهابية وهو

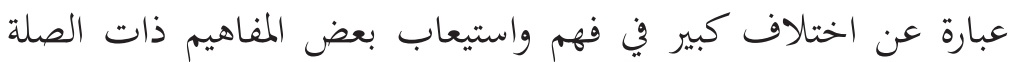

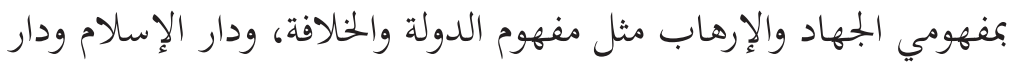

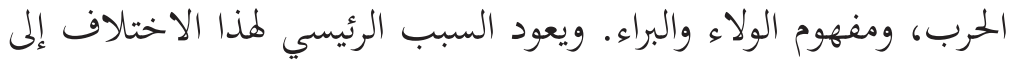

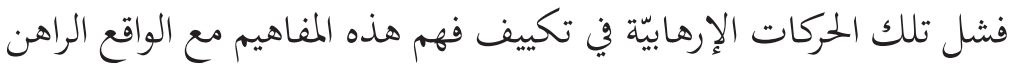
للحياة اليوم. وإن فشلهم في التمييز بين الوحي الإلهي وتعاليم الشريعة التي

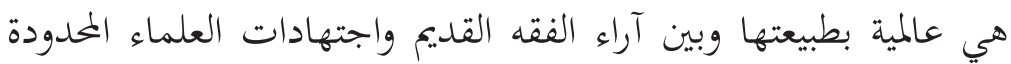
والمقيدة بالسياق القائم على واقع حياة الناس في فترة زمنية معينة سابقة المباء

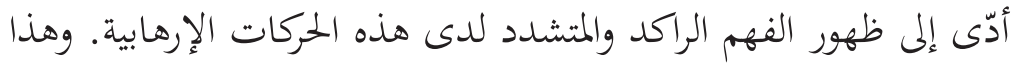

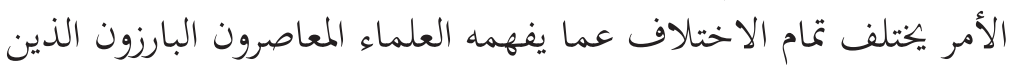

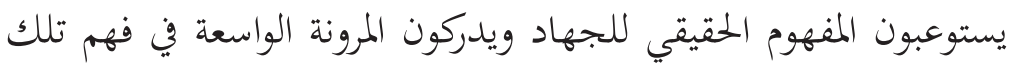

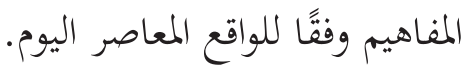

إن الجهاد محمود ومشروع وله هدفه النبيل من الأمن والسلام. بينما

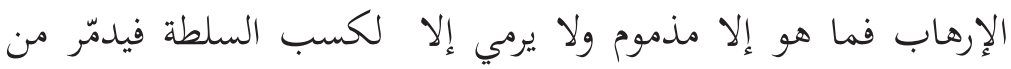

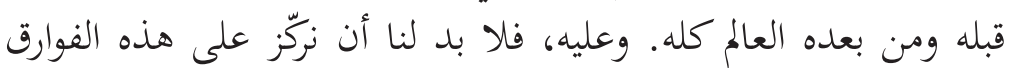

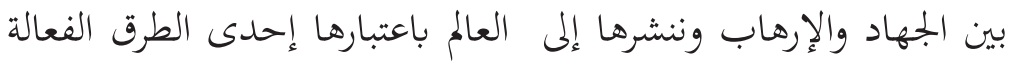

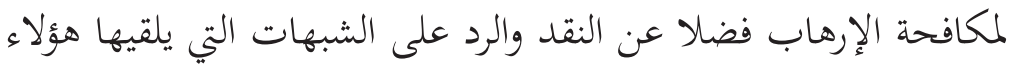
الإرهابيون على الساحات العامة باسم الإسالام والجهاد العهاد.

\section{REFERENCES}

'Abd al-Salām, Haytham. Mafhūm al-Irhāb fì al-Sharī'ah alIslāmiyyah. Bayrūt: Dār al-Kutub al-'Ilmiyyah, 2005.

Al-Bukhārī, 'Abd Allah Muḥammad Ismā'îl. Al-Jāmi' al-Saḥ̄ḥ al-Musnad min Hadīth Rasūl Allah wa Sunanuhu wa Ayyāmuhu. Qāhirah: Būlāq, 1422H. 
Al-Luwayḥiq, "Abd al-Raḥman. "Al-Islam wa al-Irhāb Mutanāqiḍān." Dawrah Tadribiyyah li Mukāfahati alIrhāb, Tunis, (2008).

Al-Naysābūrī, Muslim ibn Hajjāj. Saḥị̣ Muslim. Qāhirah: Dār Ihyā' al-Kutub al-'Arabiyyah, 1374H.

Al-Qaḥțānī, Muḥammad bin Sa'īd. Al-Walā' wa al-Barā' fì alIslām. Makkah: Dār al-Tayyibah, 1413H.

Al-Qaraḍāwī, Yūsuf. Fiqh al-Jihād: Dirāsah Muqāranah li Ahkāmihi wa Falsafatihi fì Daw'al-Qur'ān wa al-Sunnah. Qāhirah: Maktabah Wahbah, 2009.

Al-Qaraḍāwi, Yūsuf. Min Fiqh al-Dawlah fì al-Islām. Qāhirah: Dār al-Shurūq, 1997.

Al-Qarāfì, Shihāb al-Dīn. Anwār al-Burūq fì Anwā' al-Furūq, vol. 2. n.p: n.d.

Al-Sūrī, Abū Muṣ‘ab. Da 'wah al-Muqāwamah al-Islāmiyyah al'Ālamiyyah. n.p.: 2004.

Al-Ẓawāhirī, Aymān. al-Tabri'ah: Risālah fì Tabri'ah Ummah alQalam wa al-Sayf. n.p.: 2008.

Al-Zuhaylī, Wahbah. al-'Alāqāt al-Duwaliyyah fì al-Islām. Dimashq: Dār al-Maktabī, 2000.

Bin Bayah, "Abdullah. "Al-Dawlah al-Wațaniyyah fī alMujtama'at al-Muslimah." Multaqā al-Thālith li Muntadā Ta 'ziz al-Silm, Abu Zabī, (2016).

Bin Bayah, 'Abdullah. Al-Irhāb: al-Tashkhīs wa al-Hulūl. Riyāḍ: Maktabah Malik Fahd, 2007.

Chomsky, Noam. Pirates and Emperors, Old and New: International Terrorism in the Real World. London: Pluto Press, 2002.

Hallaq, Wael B. The Impossible State: Islam, Politics, and Modernity's Moral Predicament. New York: Columbia University Press, 2013.

Hassan, Muhammad Haniff. "The Danger of Takfir (Excommunication): Exposing IS' Takfiri Ideology." Counter Terrorist Trends and Analyses 9, no. 4 (2017): 3-12. Islamic State of Iraq and the Levant (ISIL). "DABIQ." Al Hayat Media Center, 2014. 
Majma' al-Fiqh al-Islāmī al-Dawlī. "Qarār bi sha'n Mawqif alIslām min al-Ghuluw wa al-Tațarruf wa al-Irhāb," Offical Website of the International Islamic Fiqh Academy. https:// www.iifa-aifi.org/ar/2206.html.

“Marrakesh Declaration.”2016.http://www.marrakeshdeclaration. org.

Negrón-Gonzales, M. "Counterterrorism Resolutions and Initiatives by Regional Institutions: Organization of Islamic Cooperation." International Human Rights (2019): 1-22. 
Jurnal Fiqh, Vol. 18 No. 2 (2021) 261-286 